\title{
ARTICLE
}

\section{Selective Potentiometric Sensors for the Determination of Quetiapine Fumarate in Pharmaceuticals and Spiked Human Urine}

\author{
Nagaraju Rajendraprasad ${ }^{1 *}$ Kanakapura Basavaiah² \\ ${ }^{1}$ Department of Chemistry, JSS College of Arts, Commerce and Science (Autonomous Institute of University of \\ Mysore), B N Road, Mysuru, Karnataka, India \\ ${ }^{2}$ University of Mysore, Mysuru, India
}

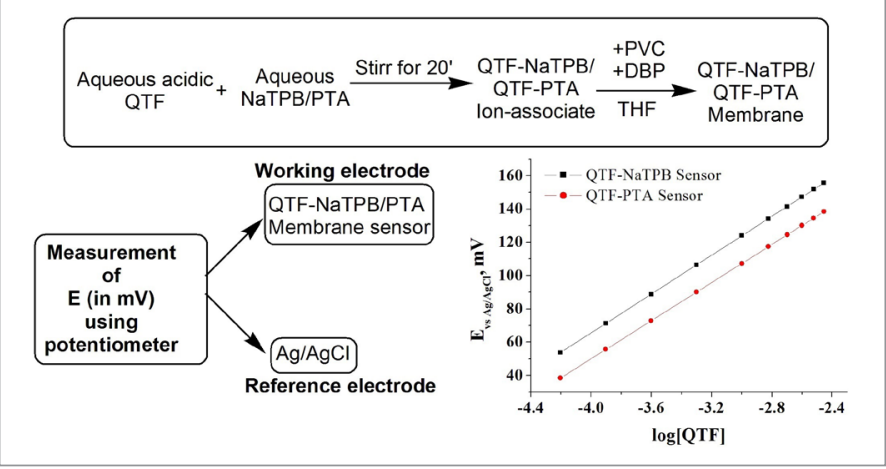

Quetiapine fumarate (QTF), chemically known as 1-[2-(2-hydroxyethoxy)-ethyl]-4-(dibenzo[b,f][1,4] thiazepin-11-yl)-piperazinium hemifumarate, is one of the derivatives of dibenzothiazepine. It is used as an atypical antipsychotic drug and is prescribed for the treatment of schizophrenia and bipolar disorders. Fabrication and the application of two selective potentiometric sensors for determination of QTF in pharmaceuticals and spiked human urine are presented. The membrane sensors are fabricated by preparing ion pair complexes of QTF with sodium tetraphenyl boron (NaTPB) and phosphotungstic acid (PTA). Using the ion-associates of QTF-NaTPB and QTF-PTA, Sensor I and Sensor II, respectively, were designed in polyvinyl chloride matrix using dibutyl phthalate as a plasticizer in THF. The fabricated Sensor I and II are applicable for the quantification QTF over the concentration range from $6.25 \times 10^{-5}$ to $3.5 \times 10^{-3} \mathrm{M}$ QTF. The operative $\mathrm{pH}$ ranges for the determination of QTF were found to be in the range from 1.5 to 2.20 and from 1.00 to 1.6, for Sensor I and II with the Nernstian slopes of $58.34 \pm 1.04$ and $57.23 \pm 0.78 \mathrm{mV} /$ decade, respectively. The regression coefficient values of 0.9992 and 0.9982 show good correlation between the measured potentials and concentrations using Sensor I and II, respectively. The limit of detection (LOD) values for the fabricated sensor are calculated and reported. The experimental conditions have been optimized to reach the effective performance characteristics of the sensors. Standard-addition procedure is followed to study the effect of additives in tablets and foreign species in spiked human urine. The results revealed no such variations due to presence of additives or foreign species or endogenous species. The fabricated sensors are subjected to validation to check accuracy, precision, robustness and ruggedness. The mean accuracy for the determination of QTF is very close to $100 \%$. The developed and validated sensors have yielded excellent results.

Cite: Rajendraprasad, N.; Basavaiah, K. Selective Potentiometric Sensors for the Determination of Quetiapine Fumarate in Pharmaceuticals and Spiked Human Urine. Braz. J. Anal. Chem., 2020, 7 (28) pp 44-69. doi: http://dx.doi.org/10.30744/ brjac.2179-3425.AR-23-2020

Submitted 22 May 2020, Resubmitted 25 June 2020, $2^{\text {nd }}$ time Resubmitted 24 July 2020, Accepted 24 July 2020 , Available online 17 August 2020. 
Keywords: Potentiometric sensor, quetiapine fumarate, determination, pharmaceuticals, spiked human urine.

\section{INTRODUCTION}

Quetiapine fumarate (QTF), chemically known as 2-[2-(4-dibenzo[b,f][1,4]thiazepin-11-yl-1-piperazinyl) ethoxy] ethanol hemifumarate (Figure 1), is an atypical antipsychotic drug used for the treatment of schizophrenia and acute episodes of bipolar disorder [1-3].

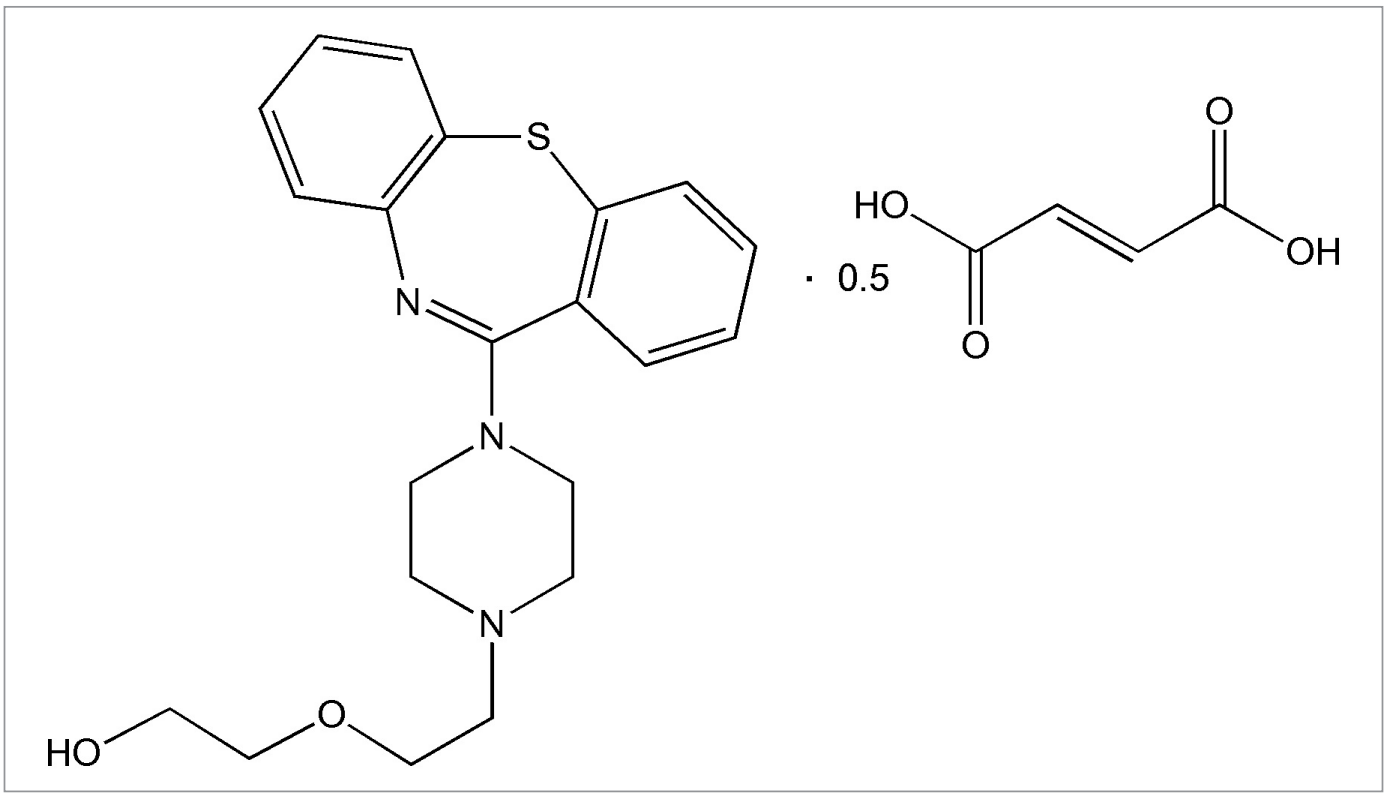

Figure 1. Structure of QTF.

QTF is not official in any Pharmacopeia. Many analytical methods are reported by different workers for the determination of QTF in pure form, formulations and in biological materials. High-performance liquid chromatography (HPLC) [4-12], ultra-performance liquid chromatographic with tandem mass spectrometry (UPLC-MS) [13,14], HPLC with different detection systems such as chemiluminescence [15], electrospray ionization mass spectrometry (ESI-MS) [16-19] and tandem mass spectrometry [20$24]$, and gas chromatography [25,26] techniques have been used for the assay of QTF in body fluids. However, QTF has been determined in pharmaceuticals by titrimetric [27,28], potentiometric [29], polarographic [30], differential pulse and square wave voltammetric [31], capillary zone electrophoretic [32,33], high performance thin layer chromatographic (HPTLC) [34-36], HPLC [12,37-41], UPLC [42] and spectrophotometric $[28,32,43-49]$ techniques.

Of the various analytical methods mentioned above, the instruments required to determine QTF in pharmaceuticals by voltammetric [30,31], capillary zone electrophoretic [32,33], high performance thin layer chromatographic (HPTLC) [34-36], HPLC [12,37-41] and UPLC [42] are highly sophisticated. Moreover, a highly skilful operator or an expertise is required to carry out the analysis. The titrimetric $[27,28]$ and the conventional potentiometric [29] techniques, although simple, are applicable for macrosize samples. Also, they consume larger volumes of organic solvents such as $\mathrm{CHCl}_{3}$ and glacial acetic acid. The spectrophotometric methods are also limited in use because they require organic and toxic solvents, extraction requirements and the maintenance of one or many stringent experimental conditions. Because of one or more limitations of the reported analytical methods, attempts are being made to develop new, simple, rapid and highly selective analytical methods for quantification of QTF in pharmaceuticals and in spiked human urine.

Potentiometry with membrane sensor electrode, also known as an ion-selective electrode (ISE), for 
analysis of organic compounds, is a highly simple technique because only the measurement of potential is involved. The selective functioning of the ISE is decided by the composition of the membrane. Therefore, membrane sensors are going to be better tools for the quantification of compounds in a hassle-free manner and without compromising selectivity and sensitivity.

The literature survey presented above indicated only one report [50] on potentiometric sensor for determination of QTF in biological and pharmaceutical samples. Fabrication of a coated wire electrode using tetraphenyl borate as ion pair complexing agent, PVC as supporting matrix, 2-nitrophenyl-octyl ether as solvent mediator and potassium tetrakis-(4-chlorophenyl) borate as lipophilic additive was described. This electrode was found to respond to QTF with a Nernstian slope of $57 \mathrm{mV} /$ decade and is selective for functioning up to 30 days only. Moreover, the detailed validation results are absent from the report.

Therefore, an attempt has been made to develop two potentiometric membrane sensors to determine QTF in pharmaceuticals and spiked human urine. The membrane sensors have been fabricated by using the ion pair complexes formed between protonated QTF $\left(\mathrm{QTFH}^{+}\right)$in acidic medium and either sodium tetraphenyl borate (Na+ TPB') or phosphotungstic acid anion (PTA') as ion-pairing agents in THF solvent using polyvinyl chloride as matrix and dibutyl phthalate (DBP) as a plasticizer. Different parameters have been optimized to improve the selectivity of membranes for the accurate and precise determination of QTF. The fabricated sensors have been used to determine QTF in pharmaceuticals to assure the selectivity of sensors to determine active component in the presence of many unknown inactive ingredients present in tablets. The sensors have also been used to determine QTF in spiked human urine to ascertain their applicability for physiotherapeutic administration of drug so that the simple means of technique can be provided to quantify QTF.

\section{MATERIALS AND METHODS}

The chemicals and reagents used were of analytical grade. Distilled water was used throughout the work. The pure QTF (99\%) was kindly provided by Cipla India Ltd, Bangalore, India. It was used without further purification. Quitipin tablets (200 mg QTF/tablet) (Sun Pharmaceuticals Laboratories Ltd., Mumbai, India) were purchased from local commercial sources. Sodium tetraphenyl boron (NaTPB), phosphotungstic acid (PTA), tetrahydrofuran (THF), dibutyl phthalate (DBP), bibutyl sebacate (DBS), dioctyl phthalate (DOP), o-nitrophenyl octylether (NPOE) and polyvinyl chloride (PVC) were supplied from S. D. Fine Chem Ltd, Mumbai, India. Concentrated sulfuric acid $\left(\mathrm{H}_{2} \mathrm{SO}_{4}\right)(98 \%$ v/v, Sp. gr. 1.84) was supplied by, S. D. Fine Chem Ltd, Mumbai, India. Urine sample was collected from a 22 year-old male healthy volunteer.

The solutions of $5.0 \mathrm{mM}$ each of NaTPB and PTA, $0.1 \mathrm{M} \mathrm{H}_{2} \mathrm{SO}_{4}, 0.5 \mathrm{M}$ each of NaOAc, $\mathrm{Na}_{2} \mathrm{CO}_{3}$, $\mathrm{NaHCO}_{3}, \mathrm{NaOH}, \mathrm{CH}_{3} \mathrm{COOH}$, glycine, $\mathrm{AgNO}_{3}$, talc, Arginine, $\mathrm{KCl}$, glucose, $\mathrm{KOH}, \mathrm{KNO}_{3}, \mathrm{KH}_{2} \mathrm{PO}_{4}, \mathrm{H}_{3} \mathrm{PO}_{4}$, $\mathrm{NaNO}_{2}$, oxalic acid, sucrose, talc, urea, cadmium chloride and cobalt chloride (all from S.D. Fine Chem Ltd., Mumbai, India) were prepared in bi-distilled water.

\section{Apparatus}

A digital dual channel potentiometer (PICO Chennai-32, India), Ag/AgCl reference electrode with the internal solution containing the saturated solutions of $\mathrm{KCl}$ and $\mathrm{AgCl}$ and copper and aluminum wires were used for potential measurements. A multichannel $\mathrm{pH}$ meter (Labtronics Ltd, Mumbai, India) was used for $\mathrm{pH}$ measurements. An Elico Conductivity meter (Hyderabad, India) was used to measure conductance.

\section{Preparation of standard QTF solution}

A standard $5.0 \mathrm{mM}$ solution of QTF was prepared by accurately dissolving a calculated quantity of pure drug in $100.0 \mathrm{~mL}$ of $0.1 \mathrm{M} \mathrm{H}_{2} \mathrm{SO}_{4}$ in a volumetric flask.

\section{General procedure}

Procedure for fabrication of sensors

Twenty five $\mathrm{mL}$ each of $5.0 \mathrm{mM}$ QTF and $5.0 \mathrm{mM}$ NaTPB or PTA solutions were transferred into a beaker 
and stirred for 30 minutes on a magnetic stirrer. The content was filtered through Whatmann $\mathrm{N}^{\circ} 40$ filter paper. The precipitate was dried for $24 \mathrm{~h}$ at room temperature. A $40 \mathrm{mg}$ of clean and dried precipitate was taken in a Petri Dish of $5 \mathrm{~cm}$ width, $300 \mathrm{mg}$ of PVC and $100 \mathrm{mg}$ of DBP were added, and the content was dissolved in $10 \mathrm{~mL}$ of THF. After mixing, the content was allowed to evaporate under room temperature for 24 hours. The thin layer of dried membrane was fused to one end of a Pyrex glass tube with the aid of THF. The tube was dried and filled with $3-5 \mathrm{~mL}$ of $5 \mathrm{mM}$ QTF solution. A pure aluminum wire $(2.0 \mathrm{~mm}$ i.d $\mathrm{d} 20 \mathrm{~cm}$ length) was tightly insulated leaving $1.0 \mathrm{~cm}$ at the ends for connection. One end of the wire was inserted into the solution of the tube and the other terminal was connected to the potentiometer. The QTF-NaTPB (Sensor I) and QTF-PTA (Sensor II) sensors were then soaked in the standard $5 \mathrm{mM}$ QTF solution at least for 1.75 and $2 \mathrm{~h}$, respectively, before use for the measurement of potential.

The sensors fabricated above were used for potential measurements. The systematic representation of the potentiometric electrochemical cell could be depicted as follows:

$$
\mathrm{Ag}-\mathrm{AgCl}_{\mathrm{Ref}} \| \mathrm{QTF}-\mathrm{NaTPB} / \mathrm{PTA} \mathrm{m}_{\mathrm{m}}\left|[\mathrm{QTF}]_{\mathrm{Int}}\right| \text { Al wire }
$$

where Ref is reference electrode, $\mathrm{m}$ is membrane and $[\mathrm{QTF}]_{\mathrm{Int}}$ meant for QTF internal solution of fixed concentration.

The Nernst equation was related between the potential and concentration of QTF [51] in the electrochemical cell used for potentiometric determination, can be written as:

$$
E_{\text {Cell }}=K+0.05916 \log [Q T F]_{\text {Sample }}
$$

where $\mathrm{K}$ accounts for the potential of the reference electrode, liquid junction potentials, the asymmetry potential, the activity coefficient of QTF and the concentration of QTF in the internal solution. Thus, this equation is to show the linear relationship between $\mathrm{E}_{\text {cell }}$ and concentration of QTF in the solution with the Nernstian slope of $\sim 60 \mathrm{mV}$. Under this background, potentiometry, as a simple technique, was employed to quantify QTF.

\section{Preparation of calibration curve}

Different volumes $(0.125,0.250,0.500,1.000, \ldots \ldots . .7 .000 \mathrm{~mL})$ of $5.0 \mathrm{mM}$ standard QTF solutions were placed into a series of $10 \mathrm{~mL}$ volumetric flasks with the help of a micro-buret. The $\mathrm{pH}$ of each solution was brought in between 1.5 and 2.2 with $0.5 \mathrm{M} \mathrm{NaOAc}$ solution or $0.1 \mathrm{M} \mathrm{H}_{2} \mathrm{SO}_{4}$. The volume of each flask was then adjusted to $10 \mathrm{~mL}$ with water, mixed the content well and transferred into a series of $25 \mathrm{~mL}$ beakers. The conditioned membrane sensor (Sensor I) and $\mathrm{Ag}-\mathrm{AgCl}$ reference electrode were immersed into the solution and recorded the potential of each solution using a pre-calibrated potentiometer. However, to measure potential using Sensor II, the $\mathrm{pH}$ of the solution was maintained in between 1 and 1.6 and the procedure followed intact.

The calibration graphs of measured potential versus log [QTF] were prepared. The concentration of the unknown was found by using calibration graphs or regression equation derived using potential versus log [QTF] data.

\section{Procedure for tablets}

Ten QTF tablets were weighed, transferred into a clean dry mortar and powdered. A portion of the tablet powder equivalent to $500 \mathrm{mg}$ of QTF was transferred into a $100 \mathrm{~mL}$ volumetric flask and shaken with 70 $\mathrm{mL}$ of $0.1 \mathrm{M} \mathrm{H}_{2} \mathrm{SO}_{4}$ for 20 minutes. The content, after diluting to the mark with the same solvent, was mixed and filtered through Whatmann No. 41 filter paper. A suitable aliquot was used and measured the potential by following the procedure as described under preparation of the calibration curve. The concentration of QTF was calculated using the calibration curve or regression data. 


\section{Procedure for spiked urine sample}

A $25.0 \mathrm{mg}$ sample of pure drug was accurately weighed and dissolved in $10 \mathrm{~mL}$ of $\mathrm{CHCl}_{3}$ in a $50 \mathrm{~mL}$ beaker and the solution was transferred into a $125 \mathrm{~mL}$ separating funnel. One milliliter of urine sample was added followed by $20 \mathrm{~mL}$ of water. The content was extracted with $10 \mathrm{~mL}$ portions of $\mathrm{CHCl}_{3}$. The triplicate extract was collected in a beaker containing anhydrous $\mathrm{Na}_{2} \mathrm{SO}_{4}$ and the solvent was evaporated to dryness on water bath. The resulted residue was dissolved in $0.1 \mathrm{M} \mathrm{H}_{2} \mathrm{SO}_{4}$ and the volume brought up to $50 \mathrm{~mL}$ with the same solvent. A suitable aliquot was then transferred into a $25 \mathrm{~mL}$ beaker, the $\mathrm{pH}$ was brought to a value between 1.5 and 2.2 (Sensor I) or 1.00 and 1.60 (Sensor II) and the solution was diluted to 10 $\mathrm{mL}$ with water. After mixing, the potential was measured using either QTF-NaTPB (Sensor I) or QTF-PTA (Sensor II) sensor as a function of $\mathrm{Ag}-\mathrm{AgCl}$ reference electrode. The concentration of QTF in the solution was calculated with the help of calibration curve or regression equation.

\section{Procedure for interference study}

Into a series of $25 \mathrm{~mL}$ beakers, $2.0 \mathrm{~mL}$ of $5.0 \mathrm{mM}$ pure drug solution and $6 \mathrm{~mL}$ of $0.1 \mathrm{M} \mathrm{H}_{2} \mathrm{SO}_{4}$ were taken. One milliliter of $0.5 \mathrm{M}$ solution of interferent was added, the $\mathrm{pH}$ was brought to the optimum value mentioned in the preparation of the calibration curve, the content was diluted to mark with water and after mixing, and the potential of each solution was measured using the electrochemical cell assembled for preparation of calibration curve.

\section{Procedure for determination of selectivity coefficient of sensors (Study of interference)}

The interference study was performed using the solutions of fixed quantity of intereferent and varying amounts of analyte at optimum $\mathrm{pH}$. Into a series of $10 \mathrm{~mL}$ beakers, varying volumes $(0.25$ to $3 \mathrm{~mL})$ of 5 $\mathrm{mM}$ solution of QTF were transferred and $1.0 \mathrm{~mL}$ of $0.5 \mathrm{M}$ interferent was added to each beaker. The $\mathrm{pH}$ in each solution was adjusted to the required level, as described above, and the final volume was brought to $10 \mathrm{~mL}$ with water. The potential of each solution was measured. The procedure was repeated for each intereferent separately.

The graph of measured potential versus log [QTF] was prepared. The point of intersection between two linear portions in the plot was located. At the point of intersection the value of selectivity coefficient $\left(\mathrm{K}_{\text {QTF. }}\right)$ was calculated by using the formula [51]:

$$
K_{Q T F . I}=\frac{[Q T F]_{E}}{[I]_{E}^{{ }^{Z_{Q T F} / Z_{I}}}}=\frac{[Q T F]_{\text {Int }}}{[I]_{\text {add }}^{{ }^{Z_{Q T F} / Z_{I}}}}
$$

where $z_{Q T F}$ and $z_{1}$ are the charges of the analyte and interferent, respectively, and $[Q T F]_{E}$ and []$_{E}$ are the concentrations of analyte and interferent yielding identical cell potentials. $[Q T F]_{\text {int }}$ is the QTF concentration in the internal solution and $[I]_{a d d}$ is the concentration of interferent added to the QTF solution.

\section{Procedure for determination of stoichiometry of ion-pair complexes}

A $10 \mathrm{~mL}$ aliquot of $0.01 \mathrm{M}$ QTF was transferred into a clean beaker and placed on a magnetic stirrer. The conductivity cell was immersed into the solution and the titration was carried out by adding $0.01 \mathrm{M}$ NaTPB or PTA. The recorded conductance values were plotted against the molar ratio of titrant and the composition of each ion-association complex was examined.

\section{RESULTS AND DISCUSSION}

The chemical reaction between protonated $\mathrm{QTF}\left(\mathrm{QTFH}{ }^{+}\right)$solution in acid medium with anion of either NaTPB or PTA yields the respective electrically neutral 1:1 ion-association complex. The aqueous insoluble ion-association complex of $\mathrm{QTFH}^{+}-\mathrm{NaTPB}$ or $\mathrm{QTFH} \mathrm{H}^{+}-\mathrm{PTA}$ is useful as a recombinant material to fabricate the membrane sensor for determination of QTF concentration. The membrane is formed effectively 
with uniform thickness all over its area when PVC and DBP were used as the matrix and plasticizer, respectively. The membranes constructed here should therefore selectively response to QTF, as the artificial ion-selective sensors. The potentiometry will enable their use to confirm the selective functioning by generating the potential difference due to the different concentrations of QTF solutions at opposite sides of the membrane [51].

\section{Composition of ion-association complex}

Preliminary experiments were carried out to deduce the reaction stoichiometry between QTF and NaTPB or PTA in the formation of ion-pair complexes. Conductometric experiments yielded satisfactory results. The stoichiometric ratio between either QTF and NaTPB or QTF and PTA was determined by conductometric titration of QTF with either NaTPB or PTA as titrant [52]. Figure 2, obtained by plotting the graphs of conductance versus molar ratio of either NaTPB or PTA, revealed the stoichiometry of 1:1 with respect to QTF and either NaTPB or PTA, which was indicated by the appearance of the equivalence point of the titration at the molar ratio of QTF with either NaTPB or PTA of 1.0. The conductance values at the beginning of the titration were absolutely due to the free cationic protonated QTF $\left(\mathrm{QTFH}^{+}\right)$. After commencing the addition of titrant there were gradual increases in the conductance up to the equivalence point. Due to a decrease in concentration of $\mathrm{QTFH}^{+}$by involving in ion-association reaction, the solution becomes diluted and hence the trend was as seen. The conductance beyond the equivalence point was assumed as presence of excess titrant in the presence of ion-associate at high concentrations. The reaction between protonated QTF $\left(\mathrm{QTFH}^{+}\right)$and anionic species of NaTPB or PTA, NaTPB- or PTA- is expected to take place as presented in Scheme 1. This influences the almost Nernstian response by the membranes while measuring the potential. Slopes of $58.34 \pm 1.04$ and $57.23 \pm 0.78 \mathrm{mV} /$ decade, respectively, for QTFNaTPB and QTF-PTA sensors, satisfied the said Nerstian response. Therefore, the reagents NaTPB and PTA were tested as active materials for development of selective membrane sensors for the determination of QTF.

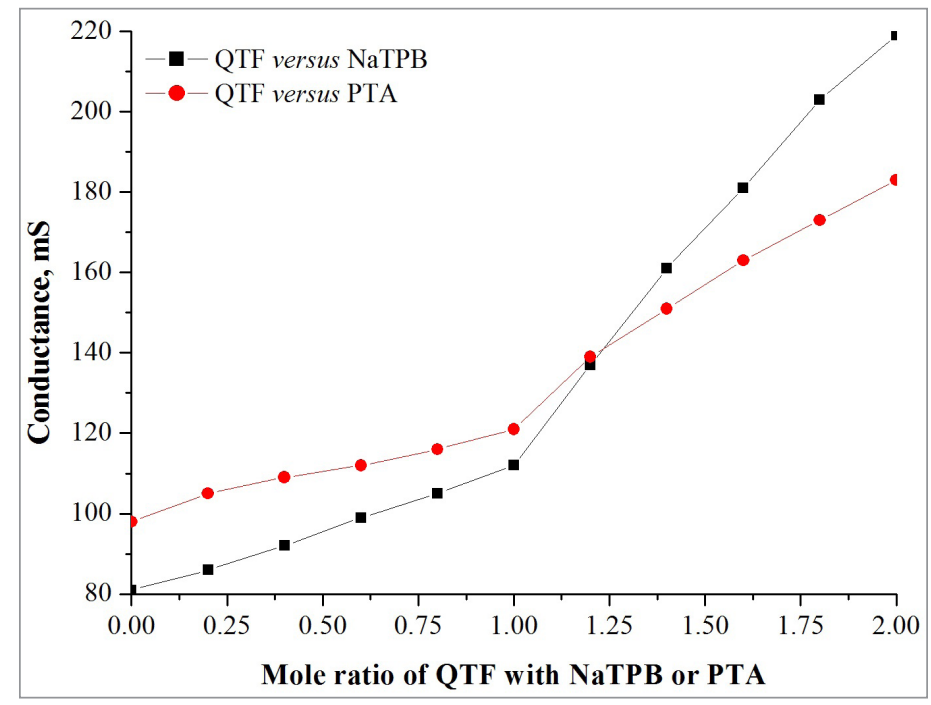

Figure 2. Variation of conductance as the function of mole ratio of QTF with either NaTPB or PTA in the formation of QTFH+-NaTPB/QTFH+'-PTA ion-association complexes. 


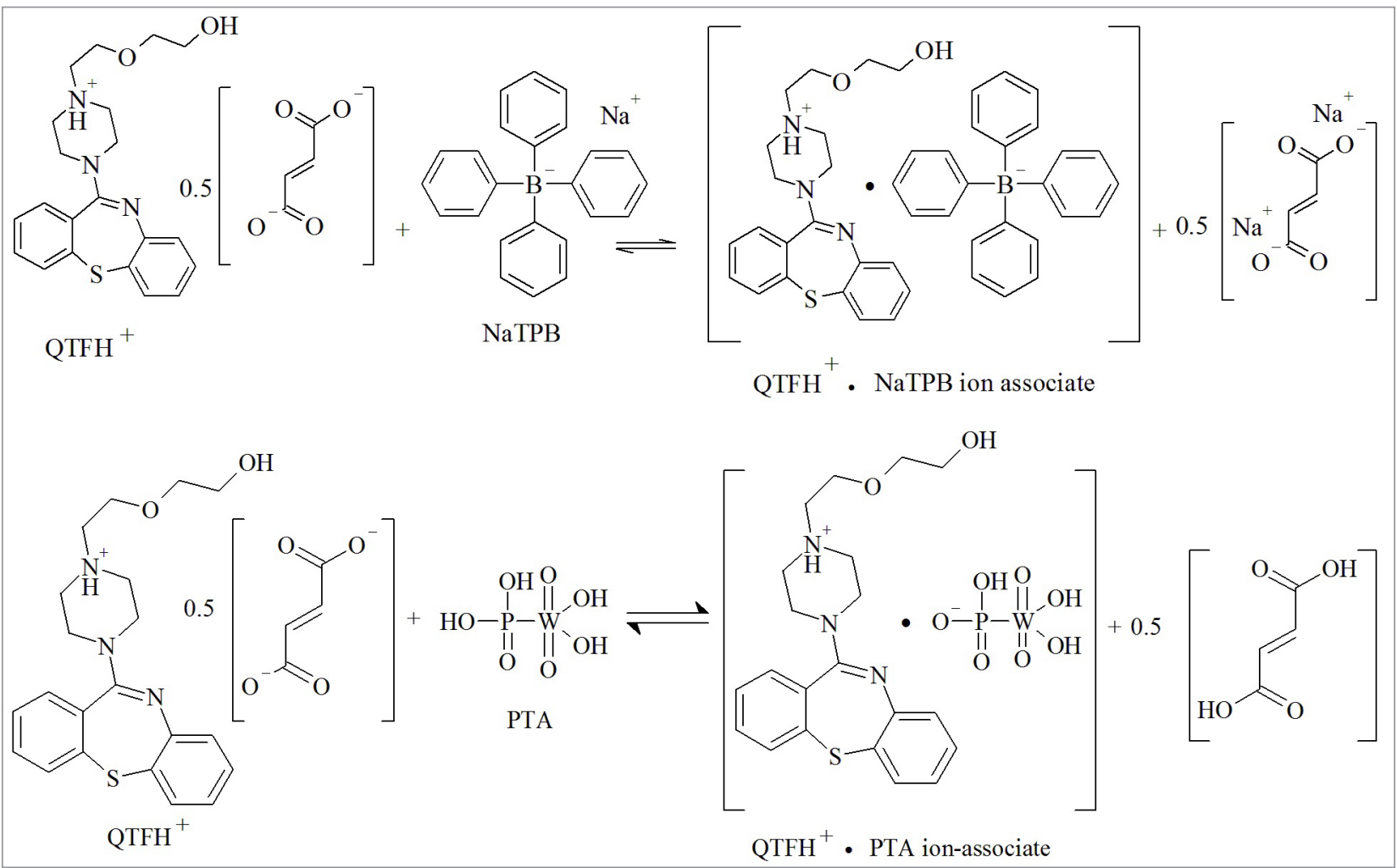

Scheme 1: Pathway of reaction in the formation of $\mathrm{QTFH}^{+}-\mathrm{NaTPB}^{-/ P T A}$ - ion-association complex.

\section{Optimization of variables}

Membrane components

At the beginning of the preparation of membranes, different amounts of materials such as ion-associate, PVC and plasticizer were used and the effective functioning for sensing QTF was evaluated by potentiometry. In the preparation of QTF-NaTPB or QTF-PTA sensors, the results of preliminary investigations showed that the membrane prepared using $40 \mathrm{mg}$ of ion-associate, $300 \mathrm{mg}$ of PVC and $100 \mathrm{mg}$ of DBP in $10 \mathrm{~mL}$ of THF was to the most convenient for use with the thickness of $0.5 \mathrm{~mm}$. The membranes prepared with lower quantities of ion-associate, PVC or plasticizer were found to have an inappropriate thickness and not to effectively function. At volumes of THF larger than $10 \mathrm{~mL}$, little variation was seen in the sensing ability of the membrane. The membranes were found to have dried completely in $24 \mathrm{~h}$ after pouring to Petri Dish; thus, the standing evaporation time was fixed as $24 \mathrm{~h}$. Thus, the procedure followed to prepare the membranes, as described above, was found as optimized. The fabricated membranes obtained results in excellent agreement with respect to linearity of the calibration curve with good Nernstian behavior.

\section{Plasticizer}

The sensing membranes were prepared separately by adding different amounts of dibutyl sebacate (DBS), dibutyl phthalate (DBP), dioctyl phthalate (DOP) and o-nitrophenyl octylether (NPOE) as plasticizers. The membranes prepared using $100 \mathrm{mg}$ of DBP for Sensor I and II were found to behave in a Nernstian manner. The sensors were found to perform satisfactorily with respect to stable potential readings, ease of conditioning and less response time. Therefore, DBP was used as plasticizer in fabricating Sensor I and II for determination of QTF. The variation of Nernstian slope of the calibration line for membrane sensors fabricated using different amounts of different plasticizer is presented in Figure 3. 


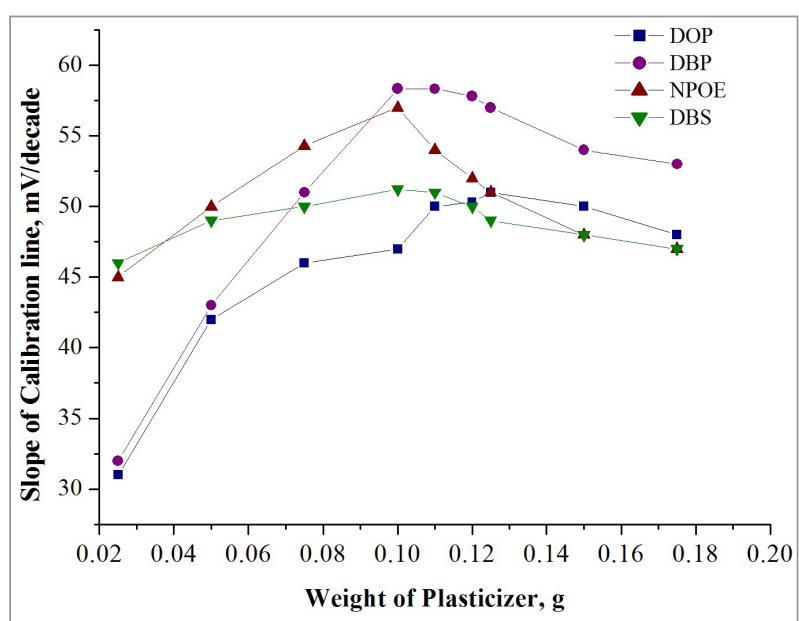

(a)

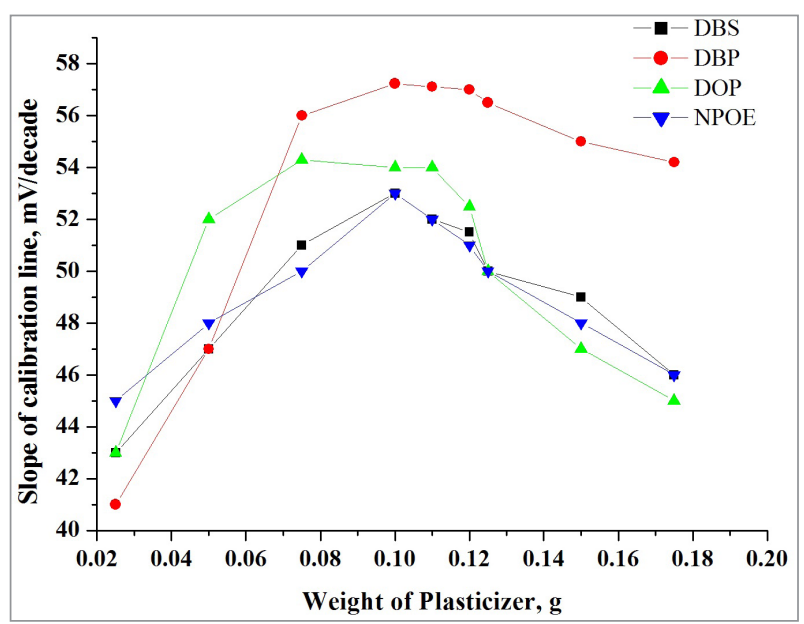

(b)

Figure 3. Effect of type and quantity of plasticizer in the fabrication of: a) QTF-NaTPB and b) QTF-PTA sensors.

\section{QTF internal solution}

The effect of the concentration of internal QTF solution on the potential response of the sensors was studied. Different trials were carried out after filling the electrode with different concentrations of QTF solution and measuring the potential of the QTF standard solutions of concentrations mentioned in preparation of calibration curves. Excellent linearity (Figure 4) between potentials and the logarithmic concentration of QTF solutions were obtained with acceptable Nernstian slope only at a QTF concentration of $5 \mathrm{mM}$ in the internal solution. At the other QTF concentrations in the internal solution, the linearity and correlations between QTF concentrations and potential values were not in good agreement. Therefore, $5 \mathrm{mM}$ QTF solution was used as an internal solution for both sensors.

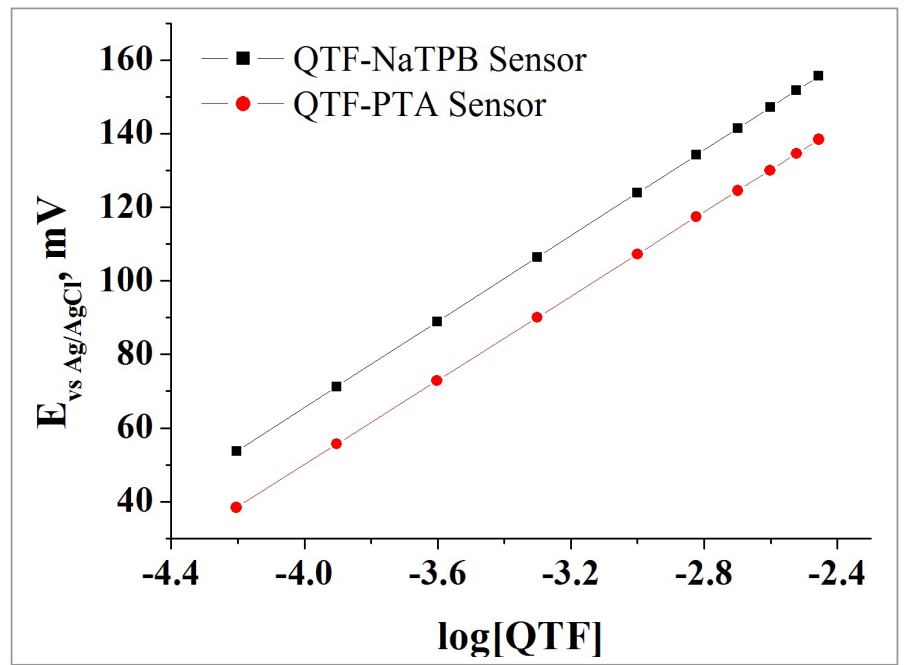

Figure 4. Calibration curves prepared by plotting the potentials of $0.125,0.25$, $0.50,1.0, \ldots \ldots . .7 .0 \mathrm{~mL}$ of $5 \mathrm{mM}$ standard QTF solutions (equivalent to 6.25 $\times 10^{-5}$ to $3.5 \times 10^{-3} \mathrm{M}$ ) of $\mathrm{pH}$ adjusted to either between 1.5 and 2.2 with QTFNaTPB sensor or between 1 and 1.6 with QTF-PTA sensor. 


\section{Choice of conducting wire}

Copper $(\mathrm{Cu})$, silver $(\mathrm{Ag})$ and aluminum (Al) wires with proper insulation to required length were used as conducting wires to immerse into the internal solution of QTF in the membrane sensors and potentials of standard QTF solutions measured. Satisfactory results were obtained with Al when compared to others. Moreover, the use of cheaper and PVC-insulated Al wire was very widely used in constructing the ionselective electrodes for determining aromatic amines [53], cationic surfactants [54], triarylmethane dyes [55], 4-aminoacetanilide [56], septonex, pilocarpine, ethylmorphine, homatrophine and cinchocaine [57], procaine and trimecaine [58], atrophine [59], cefditoren [60], etc. Therefore, an Al wire was used as medium of conductor in measuring potentials of QTF solutions using both the proposed sensors.

\section{Soaking time}

Sensor activation is an important parameter in potentiometry with membrane sensors. The surfaces of sensors were effectively activated by soaking in standard solution of analyte and the potential of the solution was expected to become constant. It was obtained that after immersing the respective sensor into analyte solution the potentials were become constant after 1.75 and $2 \mathrm{~h}$ for QTF-NaTPB and QTF-PTA sensors, respectively. Thus, these times were fixed as time duration required to make the active surface of the membrane ready for effective use at $25^{\circ} \mathrm{C}$. The effect of soaking time on the potential using QTFNaTPB and QTF-PTA sensors are presented in Figure 5. This study also revealed and recommended that the sensors may be kept dry and packed in an opaque closed vessel whenever they are out of use.

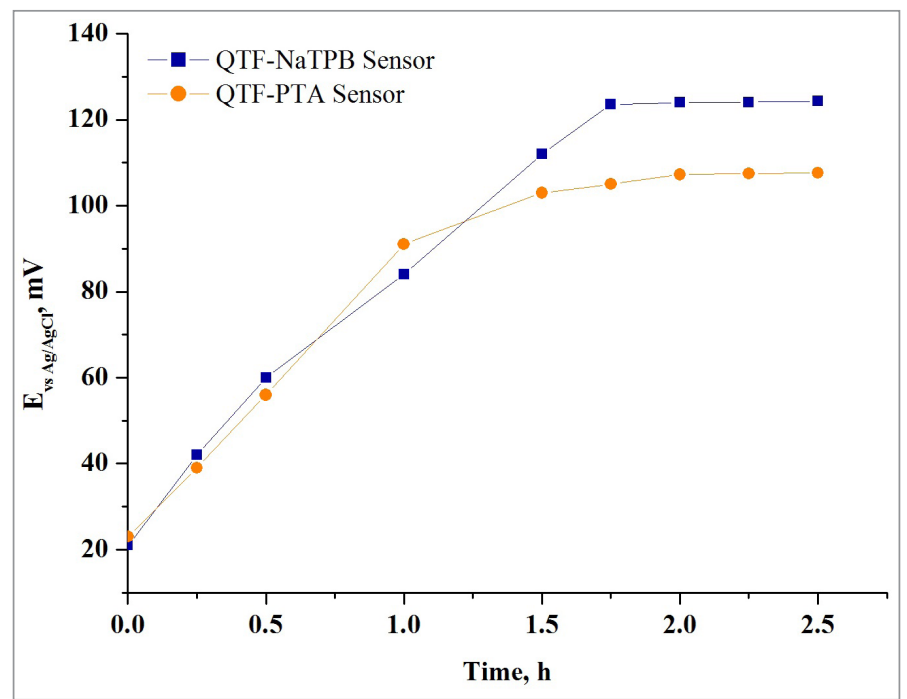

Figure 5. Effect of soaking time on potential of $1 \mathrm{mM}$ QTF solution of $\mathrm{pH}$ adjusted in between 1.5 and 2.2 while measuring with QTF-NaTPB sensor and in between 1 and 1.6 while measuring with QTF-PTA sensor.

\section{Fixing of $\mathrm{pH}$}

The effect of $\mathrm{pH}$ while measuring the potential of QTF solutions was evaluated by potential measurement. The measurements were performed by potentiometry in the $\mathrm{pH}$ range from 0.5 to 8.0 using Sensor I and II separately. The pHs of solutions were brought to the required values by adding either $0.1 \mathrm{M} \mathrm{H}_{2} \mathrm{SO}_{4}$ or $0.5 \mathrm{M} \mathrm{NaOAc}$ or $1: 5 \mathrm{NH}_{3}$ solutions. The resulted effect on potential was recorded and the consequent plot is presented in Figure 6. Less stable and lower potential values were observed at a pH less than 1.5 and greater than 2.2 with QTF-NaTPB sensor. The same trend was observed with QTF-PTA sensor at pH less than 1 and greater than 1.6. Thus, this study revealed that the $\mathrm{pH}$ ranged between 1.5 and 2.2 or 1 and 1.6 is required to be maintained for the measurement of potential of QTF solutions using Sensor I or II. 


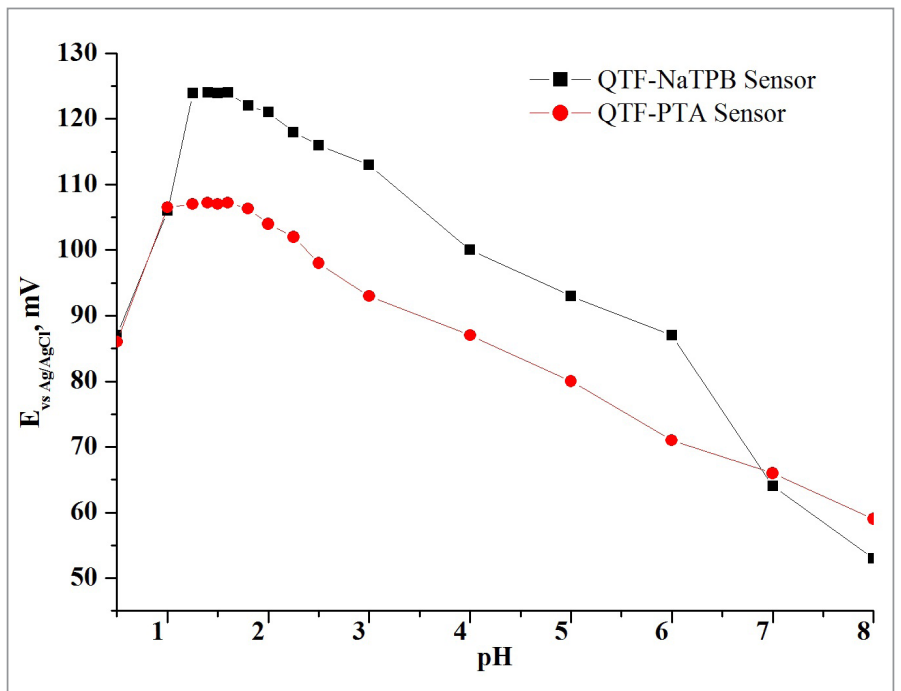

Figure 6. The effect of $\mathrm{pH}$ on potential of $1 \mathrm{mM}$ QTF solution measured using QTF-NaTPB and QTF-PTA sensors.

\section{Response time}

The experimental response time [60] for the proposed sensors was evaluated and found to be 8.0 and 12.0 s for QTF-NaTPB and QTF-PTA sensors, respectively.

\section{Life time of sensors}

The life times of QTF-NaTPB and QTF-PTA Sensors were evaluated to assess their stable and uncompromised performance ability. It was confirmed from the study that both the sensors resulted in Nernstian slopes without deviation from the actual optimum values for at least 60 days. This revealed that the sensors could be used continuously for up to 60 days. However, after 60 days, their characteristics significantly drifted away from the Nernstian behavior (Figure 7). Therefore, the average life time of QTFNaTPB and QTF-PTA Sensors were proposed as 60 days.

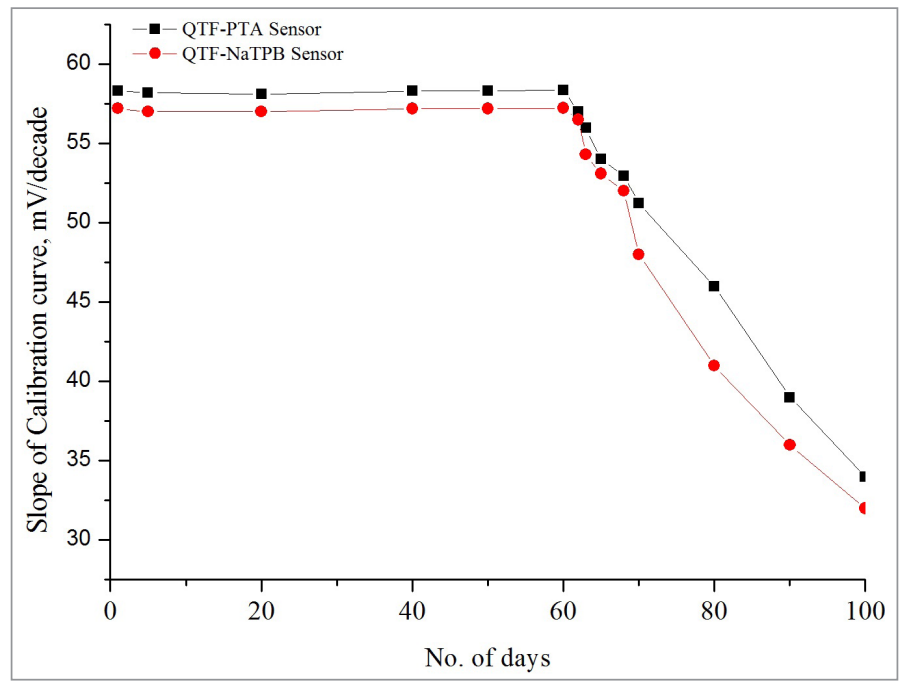

Figure 7. Life time of QTF-NaTPB and QTF-PTA Sensors. 


\section{Selectivity coefficients of sensors}

The selectivity coefficients $\left(K_{\text {QTF.I }}\right)$ of QTF-NaTPB and QTF-PTA Sensors were investigated in the presence of inorganic and organic compounds as spikes. The $\mathrm{K}_{\mathrm{QTF} \text {.I }}$ values of QTF-NaTPB and QTFPTA Sensors in the presence of various compounds have been determined experimentally by preparing a series of solutions, each of which contains the same concentration of interferent, []$_{\text {add }}$, but a different concentration of QTF and measuring the cell potential using respective sensor. A plot of potential versus the log [QTF] concentration has two distinct linear regions [51]. When the analyte's concentration is significantly larger than $K_{\mathrm{QTF} . \mathrm{I}}[]_{\mathrm{add}}$, the measured potential is a linear function of log [QTF], in the presence of interferents, as given by equation [51]:

$$
E_{\text {cell }}=K+0.05916 \log \left([Q T F]_{\text {sample }}+K_{Q T F . I}[I]^{\frac{Z_{Q T F}}{Z_{I}}}\right)
$$

where $[\mathrm{QTF}]_{\text {sample }}$ and $[\mathrm{I}]$ are the concentrations of QTF of charge $Z_{\mathrm{QTF}}$ and interferent of charge $Z_{\mathrm{I}}$ in the solutions, respectively.

If $K_{\mathrm{QTF} . \mathrm{I}}[\mathrm{l}]$ is significantly larger than the QTF's concentration, however, the cell potential remains constant. The concentration of analyte and interferent at the intersection of these two linear regions is used to calculate $K_{\text {QTF.I }}[51]$.

The values of $\mathrm{K}_{\mathrm{QTF} . \text {, }}$, presented in Table I, revealed that $\mathrm{Na}^{+}$, oxalic acid and sucrose showed significant interference with QTF while using the QTF-NaTPB Sensor. Although, sucrose is a non-ionic compound, the detectability of Sensor I was found for it. Thus, sucrose is treated as non-ionic interferent in the determination of QTF. On the other end, $\mathrm{K}^{+}$and $\mathrm{H}^{+}$ions were proved as interferents while measuring the potential of QTF with QTF-PTA sensor. The results presented below as values of $\mathrm{K}_{\mathrm{QTF} . \text {, }}$, less than unity indicated that the proposed sensors are suitable to determine QTF in the presence of interferents.

Table I. Selectivity coefficients $\left(K_{Q T F . I}\right)$ of sensors

\begin{tabular}{lcc}
\hline \multirow{2}{*}{ Interferent Species } & \multicolumn{2}{c}{ Selectivity coefficient, $\mathbf{K}_{\text {QTF.. }}{ }^{*}$} \\
\cline { 2 - 3 } & QTF-NaTPB Sensor & QTF-PTA Sensor \\
\hline $\mathrm{Cd}^{2+}$ & 0.398 & 0.417 \\
$\mathrm{~K}^{+}$ & 0.042 & 1.450 \\
$\mathrm{H}^{+}$ & 0.035 & 1.110 \\
$\mathrm{Na}^{+}$ & 1.340 & 0.053 \\
$\mathrm{H}_{3} \mathrm{PO}_{4}$ & 0.179 & 0.258 \\
$\mathrm{CH}_{3} \mathrm{COOH}$ & 0.048 & 0.072 \\
$\mathrm{Oxalic} \mathrm{acid}_{\text {Sucrose }}$ & 1.020 & 0.094 \\
Talc & 1.120 & 0.431 \\
\hline
\end{tabular}

${ }^{*}$ Mean value of three determinations

\section{Validation of sensors}

The fabricated QTF-NaTPB and QTF-PTA sensors were validated according to IUPAC recommendations $[62,63]$ and $\mathrm{ICH}$ Guidelines [64]. The validation results for individual parameters are presented in the following sections. 
Linearity of calibration curve, regression data and performance characteristics

The sensors provide a rapid, stable and linear response over the QTF concentration ranges presented in Table II. The calibration lines (Figure 4) with slopes of $58.34 \pm 1.04$ and $57.23 \pm 0.78 \mathrm{mV} /$ decade, very close to $59.2 \mathrm{mV}$, indicated the Nernstian behavior of QTF-NaTPB and QTF-PTA sensors. The regression equations for QTF-NaTPB and QTF-PTA sensors were found to be $Y=58.34 X+283$ and $Y=57.23 X+279$, respectively. The regression coefficient values of 0.9992 and 0.9982 for QTF-NaTPB and QTF-PTA sensors, respectively, showed very good linearity between measured potentials and log[QTF]. Stable potential readings but variations by $\pm 1 \mathrm{mV}$ were seen during the period of 60 days of usage of sensors. The limit of detection (LOD), calculated according to IUPAC recommendations [62,65], from the intersection of the two extrapolated linear portions of the calibration curve and other performance measurement values for QTF-NaTPB and QTF-PTA sensors are presented in Table II.

Table II. Performance characteristics of sensors with regression data

\begin{tabular}{lcc}
\hline Parameters & QTF-NaTPB Sensor & QTF-PTA Sensor \\
\hline Linear range, M & $6.25 \times 10^{-5}$ to $3.50 \times 10^{-3}$ \\
Limit of detection (LOD), M & $1.56 \times 10^{-5}$ & $2.16 \times 10^{-5}$ \\
Slope (m), mV/decade & 58.34 & 57.23 \\
Intercept (b), mV & 283 & 279 \\
Correlation coefficient & 0.9992 & 0.9982 \\
\hline
\end{tabular}

Intra- and inter-day precision and accuracy

Pure QTF solutions of three different concentrations within the calibration range were prepared in seven replicates each. Intra-day variations were evaluated by calculating the \%RSD for each concentration of QTF found. The values are presented in Table III. The pure QTF solutions of three different concentrations in five replicates were prepared and analyzed during different days for study of inter-day variations. The \%RSD values for the found QTF amounts were calculated and presented in Table III. The accuracy was evaluated by calculating the amount of QTF found in intra- and inter-day basis. The relative error (RE), the metric for accuracy, was calculated for each concentration of QTF found. The obtained \%RSD values ranged between 3.16 and $5.29 \%$, indicating the satisfactory precision of the results. The \%RE, which is an index of accuracy, ranged from 2.00 to 4.0 and indicated the acceptable accuracy in functioning of sensors. These results are summarized in Table III.

\section{Robustness and ruggedness}

The robustness of the proposed sensors was examined by deliberately changing the working $\mathrm{pH}$. The solutions of $0.5,1$ and $1.5 \mathrm{mM}$ QTF were used in the study. The \%RSD values were calculated for the obtained results. The $\mathrm{pH}$ was varied by 0.2 units at before and after the range of values for each sensor $[1.5( \pm 0.2)$ to $2.2( \pm 0.2)]$ for QTF-NaTPB and 1.0 $( \pm 0.2)$ to 1.6 $( \pm 0.2)$ for QTF-PTA sensors. For these variations, the \%RSD values calculated were ranged between 2.52 and 4.52 .

The ruggedness was checked by inter-analysts and inter-instrumental performance. The inter-analysts and inter instrumental RSD values of $\leq 3.5 \%$ showed robust functioning of QTF-NaTPB and QTF-PTA sensors. The \%RSD of robustness and ruggedness studies are presented in Table IV. 
Table III. Results of precision and accuracy

\begin{tabular}{|c|c|c|c|c|c|c|c|}
\hline \multirow[b]{2}{*}{ Sensor } & \multirow{2}{*}{$\begin{array}{l}\text { QTF taken, } \\
\text { mM }\end{array}$} & \multicolumn{3}{|c|}{ Intra-day variations } & \multicolumn{3}{|c|}{ Inter-day variations } \\
\hline & & $\begin{array}{c}\text { QTF } \\
\text { found }^{*}, \mathrm{mM}\end{array}$ & $\%$ RSD & $\% R E$ & $\begin{array}{c}\text { QTF } \\
\text { found }^{\$}, \mathrm{mM}\end{array}$ & $\%$ RSD & $\% R E$ \\
\hline \multirow{3}{*}{$\begin{array}{l}\text { QTF- } \\
\text { NaTPB }\end{array}$} & 0.50 & 0.51 & 4.23 & 2.00 & 0.52 & 4.34 & 4.00 \\
\hline & 1.00 & 1.03 & 3.16 & 3.00 & 1.04 & 4.77 & 4.00 \\
\hline & 1.50 & 1.46 & 3.22 & 4.00 & 1.47 & 4.81 & 2.00 \\
\hline \multirow{3}{*}{ QTF-PTA } & 0.50 & 0.49 & 3.98 & 2.00 & 0.48 & 5.29 & 4.00 \\
\hline & 1.00 & 1.04 & 4.67 & 4.00 & 1.04 & 5.00 & 4.00 \\
\hline & 1.50 & 1.55 & 3.56 & 3.33 & 1.45 & 4.68 & 3.33 \\
\hline
\end{tabular}

${ }^{*}$ Mean value of seven measurements; ${ }^{\$}$ Mean value of five measurements.

Table IV. Results of robustness and ruggedness (expressed in \%RSD)

\begin{tabular}{|c|c|c|c|c|}
\hline \multirow{3}{*}{ Sensor } & \multirow{3}{*}{$\begin{array}{l}\text { Concentration } \\
\text { of QTF, mM }\end{array}$} & \multicolumn{3}{|c|}{$\%$ RSD Values for varied parameters } \\
\hline & & \multirow{2}{*}{$\begin{array}{l}\text { Robustness } \\
\text { (by varying pH) }\end{array}$} & \multicolumn{2}{|c|}{ Ruggedness } \\
\hline & & & $\begin{array}{c}\text { Inter- } \\
\text { potentiometric }\end{array}$ & $\begin{array}{c}\text { Inter- } \\
\text { analysts }\end{array}$ \\
\hline \multirow{3}{*}{ QTF-NaTPB } & 0.50 & 2.59 & 2.11 & 3.14 \\
\hline & 1.00 & 3.45 & 3.09 & 3.12 \\
\hline & 1.50 & 4.51 & 3.50 & 2.93 \\
\hline \multirow{3}{*}{ QTF-PTA } & 0.50 & 2.52 & 3.29 & 2.44 \\
\hline & 1.00 & 3.98 & 2.76 & 3.12 \\
\hline & 1.50 & 4.52 & 2.77 & 2.94 \\
\hline
\end{tabular}

\section{Application of sensors to tablet analysis}

The tablet extracts in three different concentrations were subjected to analysis by potentiometry using the proposed sensors. Five replicates each of 0.5, 1.0 and $1.5 \mathrm{mM}$ QTF-containing tablet extracts were used to measure the potentials with proposed sensors by following the procedure described under 'procedure for tablets'. The amount of QTF found with percentage recoveries was calculated for each concentration. The obtained results were statistically compared with the results of reference method [32]. In the reference method, a methanolic solution of QTF was measured at $246 \mathrm{~nm}$ by UV spectrophotometry. The mean percent recoveries of QTF from tablets were found as 97.32 and 96.21 with RSD value of 1.78 and $2.17 \%$, for QTF-NaTPB and QTF-PTA, respectively. The accuracy and precision were evaluated by applying Student's $t$ - test and variance ratio F- test, respectively. The calculated $t$ - and F-values are less than the tabulated values, so it was clear from the assessment that the proposed sensors yielded accurate and precise results. The results are presented in Table V.

Table V. Results of analysis of QTF tablets using proposed sensors and statistical comparison of the results with the reference method

\begin{tabular}{|c|c|c|c|c|}
\hline \multirow{4}{*}{ Tablet analyzed } & \multirow{4}{*}{$\begin{array}{c}\text { mg of } \\
\text { QTF/Tablet }\end{array}$} & \multicolumn{3}{|c|}{ Found* } \\
\hline & & \multicolumn{3}{|c|}{$\%$ Label claim $\pm S D$} \\
\hline & & \multirow{2}{*}{$\begin{array}{l}\text { Reference } \\
\text { method }\end{array}$} & \multicolumn{2}{|c|}{ Sensor } \\
\hline & & & QTF-NaTPB & QTF-PTA \\
\hline Quitipin & 200.00 & $98.98 \pm 1.58$ & $\begin{array}{c}97.32 \pm 1.78 \\
t=1.56 \\
\mathrm{~F}=1.27\end{array}$ & $\begin{array}{c}96.21 \pm 2.17 \\
t=2.33 \\
\mathrm{~F}=1.89\end{array}$ \\
\hline
\end{tabular}

*Mean value of five determinations. The tabulated $t$ - and F-values at $95 \%$ confidence level for four degrees of freedom are 2.77 and 6.39 , respectively. 


\section{Recovery study}

The standard addition procedure was followed to further ascertain accuracy of the sensor. The solutions were prepared by spiking pure drug into a pre-analyzed tablet powder at three different levels and potential was measured using each sensor separately. Into five replicates of $3 \mathrm{~mL}$ tablets, extracts of $5 \mathrm{mM} \mathrm{QTF,} \mathrm{1,}$ 2 and $3 \mathrm{~mL}$ of $5 \mathrm{mM}$ QTF from pure drug were spiked, $\mathrm{pH}$ was adjusted to the optimum value and, after diluting to $10 \mathrm{~mL}$, the potential measured and the amounts of QTF were calculated. The percent recovery of pure QTF was computed. The percentage recovery of QTF from tablets close to $100 \%$ revealed that good and acceptable recovery values were obtained. The results of recovery study are summarized in Table VI.

Table VI. Results of recovery study for accuracy assessment by standard-addition procedure

\begin{tabular}{lccccc}
\hline Sensor & $\begin{array}{c}\text { QTF from tablet } \\
\text { extract, } \mathbf{m M}\end{array}$ & $\begin{array}{c}\text { Pure QTF } \\
\text { added, } \mathbf{m M}\end{array}$ & $\begin{array}{c}\text { Total QTF } \\
\text { found, } \mathbf{m M}\end{array}$ & $\begin{array}{c}\text { \%QTF } \\
\text { recovered }\end{array}$ & \%RSD \\
\hline \multirow{2}{*}{ QTF-NaTPB } & 1.50 & 0.50 & 1.99 & 99.00 & 2.13 \\
& 1.50 & 1.00 & 2.48 & 97.90 & 1.98 \\
QTF-PTA & 1.50 & 1.50 & 2.94 & 96.20 & 2.77 \\
\hline
\end{tabular}

${ }^{*}$ Mean value of three measurements.

\section{Spiked human urine analysis}

To ensure the suitability of developed sensors for physiotherapeutic administration of QTF by its quantification, spiked human urine sample was analyzed. A drug free urine was collected from healthy male volunteer, filtered and used for analysis by following the procedure described under 'procedures' section. After obtaining the extract from spiked human urine and after suitable dilution, completed the measurement of potential using the sensors by potentiometry. The percentage recovery of QTF from urine was calculated and reported with RSD values. The percent recovery of QTF ranged from 95.2 to 99.2 with RSD of less than $4 \%$ (Table VII) indicated the non-interference from the endogenous substances in urine. Therefore, these results held the applicability of QTF-NaTPB and QTF-PTA sensors for the analysis of urine samples to determine QTF.

Table VII. Results of analysis of spiked human urine

\begin{tabular}{lccc}
\hline Sensor & {$[\mathbf{Q T F}$ in urine, $\mathbf{m M}$} & [QTF] found, $\mathbf{m M}$ & \%QTF recovered \pm SD* \\
\hline \multirow{2}{*}{ QTF-NaTPB } & 1.00 & 0.990 & $99.00 \pm 1.23$ \\
& 1.50 & 1.469 & $97.90 \pm 2.31$ \\
& 2.00 & 1.924 & $96.20 \pm 3.67$ \\
\hline \multirow{2}{*}{ QTF-PTA } & 1.00 & 0.952 & $95.20 \pm 3.44$ \\
& 1.50 & 1.488 & $99.20 \pm 2.87$ \\
& 2.00 & 1.971 & $98.53 \pm 2.11$ \\
\hline
\end{tabular}

*Mean value of three measurements.

\section{CONCLUSIONS}

In this study, for the first time, the fabrication, optimization and application of membrane-based potentiometric sensors using sodium tetraphenyl boron (NaTPB) and phosphotungstic acid (PTA) for the selective and rapid determination of quetiapine fumarate (QTF) was described. Membranes formed by the aggregation of QTF with either NaTPB or PTA exhibit required features for use as electrochemical sensors. Simple experimental design, ease of use, better performance characteristics, selective, robust and rugged 
functioning ability are the hallmarks of the sensors. The potentiometric determination of QTF using these sensors requires a very simple instrument, so the technique is highly cost-effective. The maintenance of stringent experimental conditions is not required in the analysis. The superiority in reference to the performance characteristics of the proposed analytical methods to determine QTF over all other reported methods is highlighted in the Supplementary Material. The sensors are applicable for the determination of QTF in a wide linear range with a Nernstian response and low detection limits. The statistical comparison of results of determination of QTF using proposed sensors with those of reference method [32] revealed the selectivity and suitability of the electrodes for the accurate and precise determination of QTF in real samples. The results of the recovery study also revealed the inactive role of excipients in tablets in the determination of QTF. The sensors are also applicable for the determination of QTF in spiked human urine. The proposed potentiometric procedures to determine QTF using QTF-NaTPB and QTF-PTA sensors were found to be specific and relevant for their adoption in routine quality control and physiotherapeutic administration laboratories.

\section{Acknowledgements}

The authors are thankful to Cipla India Ltd, for providing pure quetiapine fumarate sample. The first author gratefully acknowledges the UGC, SWRO, Bengaluru, India, for financial assistance (Award No. 1495-MRP/14-15/KAMY013/UGC-SWRO, dated 04-02-15) to pursue this research work. The same author is also indebted to authorities of JSS Mahavidyapeetha and Principal of JSS College of Arts, Commerce and Science, Mysuru, for providing the facility to undertake the research work.

\section{REFERENCES}

1. Arnt, J.; Skarsfeldt, T. Neuropsychopharm, 1998, 18, pp 63-101.

2. Sweetman, S. C. (Editor) Martindale: the complete drug reference. Pharmaceutical Press; London, 2006.

3. Cheer, S. M.; Wagstaff, A. J. CNS Drugs, 2004, 18, pp 173-199.

4. Belal, F.; Elbrashy, A.; Eid, M.; Nasr, J. J. J. Liq. Chromatogr. Relat. Technol. 2008, 31, pp 1283-1298.

5. Davis, P. C.; Wonga, A. J.; Gefvertb, O. J. Pharm. Biomed. Anal., 1999, 20, pp 271-282.

6. Sachse, J.; Köller, J.; Härtter, S.; Hiemke, C. J. Chromatogr. B - Analyt. Technol. Biomed. Life Sci., 2006, 830, pp 342-348.

7. Saracino, M. A.; Mercolini, L.; Flotta, G.; Albers, L. J.; Merli, R.; Raggi, M. A. J. Chromatogr. B-Analyt. Technol. Biomed. Life Sci., 2006, 843, pp 227-233.

8. Mandrioli, R.; Fanali, S.; Ferranti, A.; Raggi, M. A. J. Pharm. Biomed. Anal., 2002, 30, pp 969-977.

9. Frahnert, C.; Rao, M. L.; Grasmader, K. J. Chromatogr. B - Analyt. Technol. Biomed. Life Sci., 2003, 794, pp 35-47.

10. Hasselstroem, J.; Linnet, K. J. Chromatogr. B - Analyt. Technol. Biomed. Life Sci., 2003, 798, pp 9-16.

11. Li, W. B.; Xue, Y. Z.; Zhai, Y. M.; Zhang, J.; Guo, G. X.; Wang, C. Y.; Cai, Z. J. Yaowu Fenxi Zazhi, 2003, 23, pp 247-251.

12. Vinay, K. B.; Revanasiddappa, H. D.; Rajendraprasad, N.; Ramesh, P. J.; Basavaiah, K. J. Rep. Pharm. Sci., 2013, 2, pp 42-50.

13. Kun-Yan, L.; Yan-Gang, Z.; Hua-Yi, R.; Feng, W.; Bi-Kui, Z.; Huan-De, L. J. Chromatogr. B., 2007, 850, pp 581-585.

14. Tu, J. Y.; Xu, P.; Xu, D. H.; Li, H. D. Chromatographia, 2008, 68, pp 525-532.

15. Bellomarino, S. A.; Brown, A. J.; Conlan, X. A.; Barnett, N. W. Talanta, 2009, 77, pp 1873-1876.

16. Li, K. Y.; Cheng, Z. N.; Li, X.; Bai, X. L.; Zhang, B. K.; Wang, F.; Li, H. D. Acta Pharmacol. Sin., 2004, 25, pp 110-114.

17. Zhou, Z. L.; Li, X.; Li, K. Y.; Xie, Z. H.; Cheng, Z. N.; Peng, W. X.; Wang, F.; Zhu, R. H.; Li, H. D. J. Chromatogr. B. - Analyt. Technol. Biomed. Life Sci., 2004, 802, pp 257-262.

18. Li, Z.; Tan, Z. R.; Ouyang, D. S.; Wang, G.; Wang, L. S.; Zhou, G.; Guo, D.; Chen, Y.; Zhou, H. Yaowu Fenxi Zazhi, 2008, 28, pp 706-708. 
19. Igor, I. M.; Natalia, V. B. J. Chromatogr. Sci., 2018, 56, pp 510-517.

20. Lin, S. N.; Chang, Y.; Moody, D. E.; Foltz. R. L. J. Anal. Tox., 2004, 28, pp 443-448.

21. Barrett, B.; Holcapek, M.; Huclova, J.; Borek-Dohalsky, V.; Fejt, P.; Nemec, B.; Jelinek, I. J. Pharm. Biomed. Anal., 2007, 44, pp 498-505.

22. Nirogi, R.; Bhyrapuneni, G.; Kandikere, V.; Mudigonda, K.; Ajjala, D.; Mukkanti, K. Biomed. Chromatogr., 2008, 22, pp 1043-1055.

23. Tan, A.; Pellerin, B.; Couture, J.; Vallée, F. SFBC Anafarm, 2006, p 1. http://www.aapsj.org/abstracts/ AM_2006/staged/AAPS2006-000989.PDF.

24. Kundlik, M. L.; Kambli, S.; Shah, V.; Patel, Y.; Gupta, S.; Sharma, R.; Zaware, B.; Kuchekar, S. R. Chromatographia, 2009, 70, pp 1587-1592.

25. McMullin, M. M. Ther. Drug Monit., 1999, 21, pp 459-459.

26. Atanasov, V. N.; Kanev, K. P.; Mitewa, M. I. Cent. Eur. J. Med., 2008, 3, pp 327-331.

27. Rajendraprasad, N.; Basavaiah, K.; Vinay, K. B. Thai. J. Pharm. Sci., 2011, 35, pp 89-97.

28. Vinay, K. B.; Revanasiddappa, H. D.; Ramesh, P. J.; Rajendraprasad, N. Chem. Ind. Chem. Eng. Q., 2011, 17, pp 99-106.

29. Vinay, K. B.; Revanasiddappa, H. D.; Rajendraprasad, N. Port. Electrochimica Acta, 2010, 28, pp 299308.

30. El-Enany, N.; El-Brashy, A.; Belal, F.; El-Bahay, N. Port. Electrochimica Acta, 2009, 27, pp 113-125.

31. Ozkan, S. A.; Dogan, B.; Uslu, B. Microchim. Acta, 2006, 153, pp 27-35.

32. Pucci, V.; Mandrioli, R.; Ferranti, A.; Furlanetto, S.; Raggi, M. A. J. Pharm. Biomed. Anal., 2003, 32, pp 1037-1044.

33. Hillaert, S.; Snoeck, L.; van den Bossche, W. J. Chromatogr. A., 2004, 1033, pp 357-362.

34. Dhandapani, B.; Somasundaram, A.; Raseed, S. H.; Raja, M.; Dhanabal, K. Int. J. PharmTech. Res., 2009, 1, pp 139-141.

35. Skibiński, R.; Komsta, Ł.; Kosztyła, I. J. Planar Chromat., 2008, 21, pp 289-294.

36. Dhaneshwar, S. R.; Patre, N. G.; Mahadik, M. V. Acta Chromatogr., 2009, 21, pp 83-93.

37. Radha, S. K.; Rao, B. M.; Someswara, N. R. Rasayan J. Chem., 2008, 1, pp 466-474.

38. Bharathi, C. H.; Prabahar, K. J.; Prasad, C. H. S.; Srinivasa Rao, M.; Trinadhachary, G. N.; Handa, V. K.; Dandala, R.; Naidu, A. Pharmazie, 2008, 63, pp 14-19.

39. Rakshit, K. T.; Mukesh C. P. Sci. Pharm., 2011, 79, pp 97-111.

40. Fu, C. M.; Wang, R. Z. Zhongguo Xinyao Zazhi, 2002, 11, pp 144-146.

41. Raju, I. V. S.; Raghuram, P.; Sriramulu, Chromatographia, 2009, 70, pp 545-550.

42. Rajendraprasad, N.; Basavaiah, K. Thai. J. Pharm. Sci., 2017, 41, pp 6-11.

43. Fursule, R. A.; Rupala, D. K.; Mujeeb Gulzar Khan, M.; Shirkhedkar, A. A.; Surana, S. J. Biosci. Biotechnol. Res. Asia, 2008, 5 (1), pp 461-463.

44. Arulappa, R. X.; Sundarapandian, M.; Venkataraman, S.; Boopathi, M.; Kaurav, M. Res. J. Pharm. Tech., 2009, 2, pp 884-885.

45. Rajendraprasad, N.; Basavaiah, K.; Vinay, K. B. Croat. Chem. Acta, 2012, 85, pp 9-17.

46. Rajendraprasad, N.; Basavaiah, K.; Vinay, K. B. Chem. Ind. Chem. Eng. Q., 2011, 17, pp 259-267.

47. Cigdem, A.; Gokhan, M. C.; Murat, L. P.; Feyyaz, O. Turk. J. Pharm. Sci., 2012, 9, pp 301-310.

48. Rajendraprasad, N.; Basavaiah, K.; Vinay, K. B. J. Pre-clin. Clin. Res., 2010, 4, pp 24-31.

49. Basavaiah, K.; Rajendraprasad, N.; Ramesh, P. J.; Vinay, K. B. Thai. J. Pharm. Sci., 2010, 34, pp 146154.

50. Hassan, A.; Majed, A. R.; Mena, E.; Amjad, F.; Ghalib, A-S. Int. J. Electrochem. Sci., 2017, 12, pp 4120 $-4133$.

51. Harvey, D. Text book of Modern Analytical Chemistry, $1^{\text {st }}$ Edition, DePauw University, International Edition, McGraw-Hill Companies, 2000, pp 475-477.

52. Khalil, M. M.; Abdel Moaty, S. A.; Korany, M. A. Sensor Actuat B-Chem. Chem., 2018, 273, pp 429-438.

53. Vytias, K.; Reme, S. M.; Kube S. H.; Svobodov A. I. Chim. Acta, 1981, 124, pp 91-98. 
54. Vytias, K.; Dajkova, M.; Mach V. Anal. Chim. Actu, 1981, 127, pp 165-172.

55. Vytias, K.; Dajkove M. Anal. Chim. Acta, 1982, 141, pp 377-382.

56. Vytias, K.; LatinBk, J.; Capoun, T.; SvobodovB, H. Chem. Prum., 1982, 32, pp 81-87.

57. Dohnal, J.; Vyttas, K. Farm. Obz., 1985, 54, pp 405-411.

58. Vytias, K.; Dlabka, V. Prir. Vedy Sk., 1985, 37, pp 182-184.

59. Matejek, S.; Vytias, K.; Stankova, S. Cesk. Farm., 1987, 36, pp 257-260.

60. Al-Tamimi, S. A.; Al-Mohaimeed, A. M.; Alarfaj, N. A.; Aly, F. A. Int. J. Electrochem. Sci., 2013, 8, pp 3988-4001.

61. Carlo. M. Anal. Chim. Acta, 2004, 512, pp 183-190

62. IUPAC Analytical Chemistry Division, "Recommendation for Nomenclature of Ion Selective Electrode". Pure and Applied Chemistry, 1994, 66, pp 2527-2536.

63. IUPAC Analytical Chemistry Division, "Potentiometric selectivity coefficients of ion selective electrodes". Pure and Applied Chemistry, 2000, 72, pp 1851-2082.

64. International Conference on Harmonization of Technical Requirements for Registration of Pharmaceuticals for Human Use, ICH Harmonized Tripartite Guideline, Validation of Analytical Procedures: Text and Methodology Q2(R 1), Complementary Guideline on Methodology dated 06 November 1996, incorporated in November 2005, London.

65. Sandeep, K.; Rahul, B.; Sanjeev, K.; Susheel, K. M.; Pritpal, S. RSC Adv., 2016, 6, pp 3150-3158. 


\section{Supplementary Material}

Comparison of performance characteristics between reported and proposed analytical methods

\begin{tabular}{|c|c|c|c|c|c|}
\hline $\begin{array}{l}\text { Technique and reagents } \\
\text { employed }\end{array}$ & Methodology & $\begin{array}{c}\text { Linear range } \\
\text { for detection of } \\
\text { QTF }\end{array}$ & $\begin{array}{l}\text { Limit of } \\
\text { detection } \\
\text { (LOD) }\end{array}$ & Remarks & $\begin{array}{c}\text { Reference } \\
\text { No. }\end{array}$ \\
\hline $\begin{array}{l}\text { A reversed-phase high performance } \\
\text { liquid chromatography (RPHPLC). } \\
\text { Column: } 250 \mathrm{~mm} \times 4.6 \mathrm{~mm} \text { i.d., } 5 \mu \mathrm{m} \\
\text { particle size Zorbax SB-Phenyl. Mobile } \\
\text { phase (MP): Mixture of acetonitrile } \\
\text { and } 0.02 \mathrm{M} \text { phosphate buffer }(50: 50) \\
(\mathrm{pH}=5.5)\end{array}$ & $\begin{array}{l}\text { Elution of QTF with UV detection } \\
\text { made at } 254 \mathrm{~nm}\end{array}$ & $0.08-20 \mu \mathrm{g} \mathrm{mL}-1$ & $0.03 \mu \mathrm{g} \mathrm{mL}^{-1}$ & $\begin{array}{l}\text { Require sophisticated instrument } \\
\text { and larger volumes of toxic } \\
\text { organic solvents. } \\
\text { Applicable to tablets and human } \\
\text { plasma. }\end{array}$ & 4 \\
\hline $\begin{array}{l}\text { Extraction and HPLC } \\
\text { Column: A narrow bored ZORBAX } \\
\text { Stable bond phenyl (SB-Ph) column } \\
(150 \times 2.1 \mathrm{~mm}, 5 \mu \mathrm{m}) \\
\text { MP: } 20 \mathrm{mM} \text { Phosphate buffer }(\mathrm{pH} 7.4) \text {, } \\
\text { methanol and acetonitrile }(40: 50: 10, \\
\text { v/v/v). } \\
\text { The injection solvent: Phosphate buffer } \\
(\mathrm{pH} 7.4), \text { methanol and acetonitrile } \\
(60: 30: 10, \mathrm{v} / \mathrm{v} / \mathrm{v})\end{array}$ & $\begin{array}{l}\text { Liquid-liquid extraction of quetiapine } \\
\text { and its 7-hydroxylated and } \\
\text { 7-hydroxylated, N-dealkylated } \\
\text { metabolites from human plasma, and } \\
\text { UV (at } 225 \mathrm{~nm} \text { ) and electrochemical } \\
\text { detection of QTF made }\end{array}$ & $500-5000 \mathrm{ng} \mathrm{mL}^{-1}$ & - & $\begin{array}{l}\text { Require sophisticated instrument. } \\
\text { Tedious extraction procedure } \\
\text { involved. Applicable to plasma } \\
\text { samples. }\end{array}$ & 5 \\
\hline $\begin{array}{l}\text { HPLC method } \\
\text { Column: ODS Hypersil C18 } \\
\text { MP: Acetonitrile-water- } \\
\text { tetramethylethylenediamine } \\
(37.5: 62.1: 0.4, \mathrm{v} / \mathrm{v} / \mathrm{v}),(\mathrm{pH} 6.5)\end{array}$ & $\begin{array}{l}\text { Separation of quetiapine from } \\
\text { clozapine, norclozapine, perazine } \\
\text { and olanzapine in blood samples. } \\
\text { UV detection made at } 254 \mathrm{~nm}\end{array}$ & $20-370 \mathrm{ng} \mathrm{mL}^{-1}$ & - & $\begin{array}{l}\text { Applicable for separation of } \\
\text { QTF in blood samples. Require } \\
\text { sophisticated instrument. }\end{array}$ & 6 \\
\hline 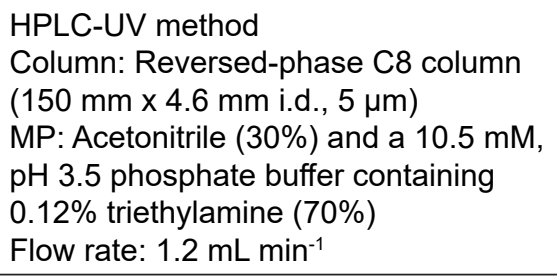 & $\begin{array}{l}\text { Sample pretreatment was carried out } \\
\text { by an original solid-phase extraction } \\
\text { (SPE) procedure. UV detection of } \\
\text { eluate at } 245 \mathrm{~nm}\end{array}$ & $2.5-400 \mathrm{ng} \mathrm{mL}^{-1}$ & - & $\begin{array}{l}\text { Applicable for simultaneous } \\
\text { determination of fluvoxamine and } \\
\text { QTF in human plasma samples. } \\
\text { Require sophisticated instrument. }\end{array}$ & 7 \\
\hline $\begin{array}{l}\text { HPLC-UV method } \\
\text { Column: C8 ( } 150 \times 4.6 \mathrm{~mm} \text { i.d., } 5 \mu \mathrm{m}) \\
\text { MP: Mixture of acetonitrile, methanol } \\
\text { and pH } 1.9 \text { phosphate buffer }\end{array}$ & $\begin{array}{l}\text { Pre-treatment of sample for SPE. } \\
\text { Detection of HPLC eluate at } 254 \mathrm{~nm}\end{array}$ & $4-400 \mathrm{ng} \mathrm{mL}^{-1}$ & - & $\begin{array}{l}\text { SPE and sophisticated } \\
\text { instruments required. Applicable } \\
\text { to human plasma samples. }\end{array}$ & 8 \\
\hline
\end{tabular}


Comparison of performance characteristics between reported and proposed analytical methods (Continuation)

\begin{tabular}{|c|c|c|c|c|c|}
\hline $\begin{array}{l}\text { Technique and reagents } \\
\text { employed }\end{array}$ & Methodology & $\begin{array}{c}\text { Linear range } \\
\text { for detection of } \\
\text { QTF }\end{array}$ & $\begin{array}{l}\text { Limit of } \\
\text { detection } \\
\text { (LOD) }\end{array}$ & Remarks & $\begin{array}{c}\text { Reference } \\
\text { No. }\end{array}$ \\
\hline $\begin{array}{l}\text { HPLC-UV method } \\
\text { Column: Nucleosil 100-Protect } 1 \\
\text { MP: Acetonitrile (60\%)- } 25 \mathrm{mM} \\
\text { potassium dihydrogenphosphate buffer } \\
(40 \%)(\mathrm{pH} 7.0) \\
\text { Flow rate: } 1.0 \mathrm{~mL} \mathrm{~min}{ }^{-1}\end{array}$ & $\begin{array}{l}\text { Separation and elution of } 18 \\
\text { antidepressants and detection of } \\
\text { QTF at } 230 \mathrm{~nm}\end{array}$ & $5-1000 \mathrm{ng} \mathrm{mL}^{-1}$ & - & $\begin{array}{l}\text { Sophisticated instrument } \\
\text { required. Applicable to serum } \\
\text { analysis. }\end{array}$ & 9 \\
\hline $\begin{array}{l}\text { HPLC method } \\
\text { Column: Silica } \\
\text { MP: A } 99: 1 \text { mixture of methanol and } \\
\text { ammonium acetate }(\mathrm{pH} 5.0) \\
\text { Flow rate: } 1.0 \mathrm{~mL} \mathrm{~min}^{-1}\end{array}$ & $\begin{array}{l}\text { Separation by SPE and elution by } \\
\text { HPLC. UV detection at } 257 \mathrm{~nm}\end{array}$ & $50-5000 \mathrm{nM}$ & $10 \mathrm{nM}$ & $\begin{array}{l}\text { SPE and HPLC techniques are } \\
\text { sophisticated. Applicable to } \\
\text { serum samples. }\end{array}$ & 10 \\
\hline HPLC method & Elution of QTF by HPLC & - & - & $\begin{array}{l}\text { Sophisticated instrument } \\
\text { required. Applicable to serum } \\
\text { samples. }\end{array}$ & 11 \\
\hline $\begin{array}{l}\text { HPLC method } \\
\text { Column: ODS }(250 \mathrm{~mm} \times 4.6 \mathrm{~mm} \text { i.d., } \\
5 \mu \mathrm{m}) \\
\text { Chromatopack } \\
\text { MP: Mixture of acetonitrile and } 0.1 \% \\
\text { phosphate buffer }(\mathrm{pH} 3.1)(40: 60) \\
\text { Flow rate: } 1.0 \mathrm{~mL} \mathrm{~min}{ }^{-1}\end{array}$ & Elution and detection at $240 \mathrm{~nm}$ & $0.09-18 \mu \mathrm{g} \mathrm{mL}^{-1}$ & $0.03 \mu \mathrm{g} \mathrm{mL}^{-1}$ & $\begin{array}{l}\text { Sophisticated instrument } \\
\text { required. Applicable to spiked } \\
\text { human urine samples and } \\
\text { pharmaceuticals. }\end{array}$ & 12 \\
\hline $\begin{array}{l}\text { UPLC-ESI-MS/MS method } \\
\text { Column: Acquity UPLC }{ }^{\mathrm{TM}} \mathrm{BEH} \\
\mathrm{C}_{18} \text { column }(100 \mathrm{~mm} \times 2.1 \mathrm{~mm} \text { i.d., } \\
1.7 \mu \mathrm{m}) \\
\text { MP: } 62: 38 \text { Acetonitrile and ammonium } \\
\text { acetate at a final concentration of } 30 \\
\text { mmol/l }\end{array}$ & $\begin{array}{l}\text { Separation and determination of } \\
\text { quetiapine, perospirone, aripiprazole } \\
\text { and quetiapine sulfoxide in in vitro } \\
\text { samples. } \\
\text { Tandem quadrupole mass } \\
\text { spectrometric detection made. }\end{array}$ & $0.05-5 \mu g \mathrm{~L}^{-1}$ & $<0.005 \mu \mathrm{g} \mathrm{L}^{-1}$ & $\begin{array}{l}\text { Highly sophisticated instrument } \\
\text { required. } \\
\text { Not applicable to determine QTF } \\
\text { in pharmaceuticals. }\end{array}$ & 13 \\
\hline UPLC-MS/MS method & $\begin{array}{l}\text { Separation and detection of } \\
\text { quetiapine and its two active } \\
\text { metabolites, 7-hydroxyquetiapine } \\
\text { and 7-hydroxy-Ndealkylquetiapine. }\end{array}$ & - & - & $\begin{array}{l}\text { Highly sophisticated instrument } \\
\text { required. } \\
\text { Applicable for assay of QTF in rat } \\
\text { plasma and cerebrospinal fluid. }\end{array}$ & 14 \\
\hline
\end{tabular}


Comparison of performance characteristics between reported and proposed analytical methods (Continuation)

\begin{tabular}{|c|c|c|c|c|c|}
\hline $\begin{array}{l}\text { Technique and reagents } \\
\text { employed }\end{array}$ & Methodology & $\begin{array}{c}\text { Linear range } \\
\text { for detection of } \\
\text { QTF }\end{array}$ & $\begin{array}{l}\text { Limit of } \\
\text { detection } \\
\text { (LOD) }\end{array}$ & Remarks & $\begin{array}{c}\text { Reference } \\
\text { No. }\end{array}$ \\
\hline $\begin{array}{l}\text { HPLC with tris(2,2'-bipyridyl) } \\
\text { ruthenium(II) chemiluminescence } \\
\text { detection method } \\
\text { Column: Chromolith Performance RP- } \\
18 \mathrm{e} 100 \mathrm{~mm} \times 4.6 \mathrm{~mm} \text { (Analytical) and } \\
5 \mathrm{~mm} \text { monolithic (guard column) } \\
\text { MP: Mixture of methanol and trifluoro } \\
\text { acetic acid }\end{array}$ & $\begin{array}{l}\text { HPLC separations with tris }(2,2 \\
\text {-bipyridyl) ruthenium(II) } \\
\text { chemiluminescence detection } \\
\text { and estimation of quetiapine. The } \\
\text { observation of major metabolites of } \\
\text { QTF }\end{array}$ & $\begin{array}{c}20 \mu \mathrm{L} \text { injection: } \\
1 \times 10^{-7}-1 \times 10^{-4} \\
\mathrm{M} \\
100 \mu \mathrm{L} \text { injection: } \\
1 \times 10^{-8}-1 \times 10^{-4} \mathrm{M}\end{array}$ & $\begin{array}{l}7 \times 10^{-8} \mathrm{M} \\
2 \times 10^{-10} \mathrm{M}\end{array}$ & $\begin{array}{l}\text { Sophisticated instrument } \\
\text { required. } \\
\text { Applicable to analyze body fluids. }\end{array}$ & 15 \\
\hline HPLC-MS/MS-solid phase extraction & $\begin{array}{l}\text { SPE separation followed by } \\
\text { elution by HPLC and detection } \\
\text { by electrospray characterization } \\
\text { technique }\end{array}$ & $\begin{array}{c}1.1 \times 10^{-9} \text { to } 4.3 \times \\
10^{-7} \mathrm{M}\end{array}$ & $3.3 \times 10^{-10} \mathrm{M}$ & $\begin{array}{l}\text { Sophisticated instrument } \\
\text { required. } \\
\text { Applicable to human serum } \\
\text { samples. }\end{array}$ & 16 \\
\hline $\begin{array}{l}\text { HPLC electrospray ionization mass } \\
\text { spectrometry } \\
\text { Column: C18 }(2.0 \mathrm{~mm} \times 125 \mathrm{~mm}, 3 \mu \mathrm{m} \\
\text { MP: Formic acid }(2.70 \mathrm{~mol} / \mathrm{l}) \text {, ammonium } \\
\text { acetate }(10 \mathrm{mmol} / \mathrm{l}) \text {-acetonitrile (53:47) } \\
\text { Flow rate: } 16 \mathrm{ml} / \mathrm{min}\end{array}$ & $\begin{array}{l}\text { Simultaneous determination of } \\
\text { clozapine, olanzapine, risperidone } \\
\text { and quetiapine by the use of high- } \\
\text { performance liquid chromatography- } \\
\text { electrospray ionization mass } \\
\text { spectrometry }\end{array}$ & $20-1000 \mathrm{ng} \mathrm{mL}^{-1}$ & - & $\begin{array}{l}\text { Sophisticated technique } \\
\text { employed. Suitable to determine } \\
\text { QTF simultaneously with other } \\
\text { drugs. }\end{array}$ & 17 \\
\hline $\begin{array}{l}\text { HPLC-electrospray ionization mass } \\
\text { spectrometry }\end{array}$ & $\begin{array}{l}\text { High-performance liquid } \\
\text { chromatography-electrospray } \\
\text { ionization mass spectrometry assay } \\
\text { of QTF }\end{array}$ & - & - & $\begin{array}{l}\text { Sophisticated technique } \\
\text { employed. Applicable for } \\
\text { assaying QTF in body fluids. }\end{array}$ & 18 \\
\hline $\begin{array}{l}\text { Liquid chromatography- electrospray } \\
\text { ionization mass spectrometry } \\
\text { Column: Zorbax SB-C18 }(150 \mathrm{~mm} \times 4.6 \\
\mathrm{mm}, 5 \mu \mathrm{m}) \\
\text { MP: Mixture of acetonitrile and } 0.2 \% \\
\text { aqueous solution of formic acid } \\
\text { FR: } 0.6 \mathrm{~mL} \mathrm{~min}^{-1}\end{array}$ & $\begin{array}{l}\text { Extraction of QTF from the samples } \\
\text { containing eight antipsychotic } \\
\text { drugs: chlorpromazine, haloperidol, } \\
\text { zuclopenthixol, clozapine, } \\
\text { risperidone, quetiapine, aripiprazole } \\
\text { or olanzapine and some active } \\
\text { metabolites. The determination of } \\
\text { QTF by electrospray ionization mass } \\
\text { spectrometry }\end{array}$ & $1-1000 \mathrm{ng} \mathrm{mL}^{-1}$ & - & $\begin{array}{l}\text { Highly sophisticated instrument } \\
\text { required. }\end{array}$ & 19 \\
\hline
\end{tabular}


Comparison of performance characteristics between reported and proposed analytical methods (Continuation)

\begin{tabular}{|c|c|c|c|c|c|}
\hline $\begin{array}{l}\text { Technique and reagents } \\
\text { employed }\end{array}$ & Methodology & $\begin{array}{c}\text { Linear range } \\
\text { for detection of } \\
\text { QTF }\end{array}$ & $\begin{array}{l}\text { Limit of } \\
\text { detection } \\
\text { (LOD) }\end{array}$ & Remarks & $\begin{array}{l}\text { Reference } \\
\text { No. }\end{array}$ \\
\hline HPLC-MS/MS method determination & $\begin{array}{l}\text { HPLC-MS/MS determination of } \\
\text { QTF by tandem mass spectrometric } \\
\text { detection }\end{array}$ & - & - & \multirow{2}{*}{$\begin{array}{l}\text { Sophisticated technique } \\
\text { employed. Applicable for } \\
\text { assaying QTF in plasma. }\end{array}$} & 20 \\
\hline SPE \& HPLC-MS/MS method & $\begin{array}{l}\text { Extraction by SPE, analysis of QTF } \\
\text { by HPLC-MS/MS and detection } \\
\text { by tandem mass spectrometric } \\
\text { detection }\end{array}$ & $1.0-382.2 \mathrm{ng} \mathrm{mL}^{-1}$ & - & & 21 \\
\hline $\begin{array}{l}\text { Liquid-liquid extraction and HPLC- } \\
\text { tandem MS } \\
\text { Column: Zorbax C8, } 50 \times 4.6 \mathrm{~mm} \\
\text { MP: } 10 \mathrm{mM} \text { Ammonium acetate and } \\
\text { acetonitrile }\end{array}$ & $\begin{array}{l}\text { Sample preparation by solvent } \\
\text { extraction, separation by LC } \\
\text { and tandem mass spectrometric } \\
\text { detection of QTF }\end{array}$ & $0.25-500 \mathrm{ng} \mathrm{mL}^{-1}$ & - & $\begin{array}{l}\text { Highly sophisticated LC-MS/MS } \\
\text { in positive electrospray ionization } \\
\text { technique using multiple reaction } \\
\text { monitoring system required. } \\
\text { Applicable to rat plasma. }\end{array}$ & 22 \\
\hline SPE and LC-MS/MS technique & $\begin{array}{l}\text { Sample preparation by SPE, elution } \\
\text { by LC and detection tandem mass } \\
\text { spectrometry }\end{array}$ & - & - & & 23 \\
\hline 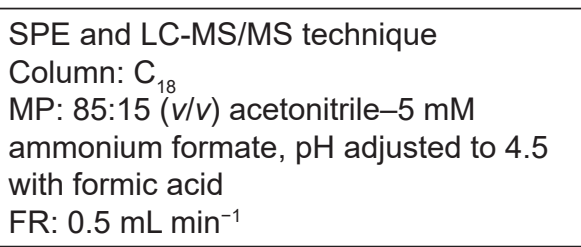 & $\begin{array}{l}\text { Extraction of plasma sample by SPE } \\
\text { and LC-MS detection of QTF by } \\
\text { tandem mass spectrometry }\end{array}$ & $1-240 \mathrm{ng} \mathrm{mL}^{-1}$ & - & $\begin{array}{l}\text { Highly sophisticated LC-MS/MS } \\
\text { technique required. Applicable to } \\
\text { human plasma. }\end{array}$ & 24 \\
\hline GC-MS technique & Detection of QTF by GC-MS & - & - & & 25 \\
\hline $\begin{array}{l}\text { GC-MS technique } \\
\text { Column: Capillary fused silica (DB-5 } \\
\text { MS) }(30 \mathrm{~m} \times 0.25 \mathrm{~mm} \text { ID } \times 0.25 \mu \mathrm{m} \text { film) } \\
\text { MP: He gas }\end{array}$ & $\begin{array}{l}\text { GC-MS detection of QTF in the scan } \\
\text { mode from } 33-460 \mathrm{~m} / \mathrm{z}\end{array}$ & - & - & $\begin{array}{l}\text { Sophisticated instrument } \\
\text { required. }\end{array}$ & 26 \\
\hline \multirow[t]{2}{*}{$\begin{array}{l}\text { lon-pair titrimetric assay of QTF using } \\
\text { NaTPB and SDS }\end{array}$} & $\begin{array}{l}\text { Solvent extraction-titration of QTF } \\
\text { with: } \\
\text { i. NaTPB }\end{array}$ & $4-18 \mathrm{mg}$ & - & \multirow{2}{*}{$\begin{array}{l}\text { Titrimetry require large sized } \\
\text { samples. } \\
\text { Less sensitive. }\end{array}$} & \multirow[t]{2}{*}{27} \\
\hline & ii. SDS & $5-25 \mathrm{mg}$ & - & & \\
\hline
\end{tabular}


Comparison of performance characteristics between reported and proposed analytical methods (Continuation)

\begin{tabular}{|c|c|c|c|c|c|}
\hline $\begin{array}{l}\text { Technique and reagents } \\
\text { employed }\end{array}$ & Methodology & $\begin{array}{l}\text { Linear range } \\
\text { for detection of } \\
\text { QTF }\end{array}$ & $\begin{array}{l}\text { Limit of } \\
\text { detection } \\
\text { (LOD) }\end{array}$ & Remarks & $\begin{array}{c}\text { Reference } \\
\text { No. }\end{array}$ \\
\hline \multirow[t]{2}{*}{ Titrimetry and spectrophotometry } & $\begin{array}{l}\text { Non-aqueous titration of QTF with } \\
0.01 \mathrm{M} \text { perchloric acid in acetic acid } \\
\text { medium }\end{array}$ & $2.0-20.0 \mathrm{mg}$ & - & $\begin{array}{l}\text { Least sensitive and applicable to } \\
\text { macro-size samples. }\end{array}$ & \multirow[t]{2}{*}{28} \\
\hline & $\begin{array}{l}\text { Measurement of QTF in } \\
0.1 \mathrm{M} \text { acetic acid } \\
\text { spectrophotometrically at a } \\
\text { wavelength of } 222 \mathrm{~nm}\end{array}$ & $1.25-15.0 \mu \mathrm{g} \mathrm{mL}^{-1}$ & $0.07 \mu \mathrm{g} \mathrm{mL}^{-1}$ & $\begin{array}{l}\text { Measurement made at shorter } \\
\text { wavelength. }\end{array}$ & \\
\hline Potentiometric method & $\begin{array}{l}\text { Potentiometric titration of QTF with } \\
0.01 \mathrm{M} \text { perchloric acid in acetic acid } \\
\text { medium }\end{array}$ & $2-20 \mathrm{mg}$ & - & $\begin{array}{l}\text { Less sensitive. } \\
\text { Applicable to macro-size } \\
\text { samples. }\end{array}$ & 29 \\
\hline \multirow{2}{*}{$\begin{array}{l}\text { Polarographic method: } \\
\text { Dropping mercury working electrode } \\
\text { (DME), Ag/AgCl reference electrode, } \\
\text { and a graphite rod as the auxiliary } \\
\text { electrode }\end{array}$} & $\begin{array}{l}\text { The study of voltammetric } \\
\text { characterization of QTF by } \\
\text { i. direct current, differential pulse and }\end{array}$ & $8-44 \mu \mathrm{g} \mathrm{mL}-1$ & $0.06 \mu \mathrm{g} \mathrm{mL}^{-1}$ & \multirow{3}{*}{$\begin{array}{l}\text { Analysis prone to get interfered } \\
\text { by atmospheric components. }\end{array}$} & 30 \\
\hline & ii. alternating current polarography & $4-44 \mu \mathrm{g} \mathrm{mL}-1$ & $0.04 \mu \mathrm{g} \mathrm{mL}^{-1}$ & & \\
\hline $\begin{array}{l}\text { Differential pulse (DP) and Osteryoung } \\
\text { square wave (OSW) voltammetry }\end{array}$ & $\begin{array}{l}\text { Study of electrochemical } \\
\text { characterization of QTF by } \\
\text { voltammetric techniques using } \\
\text { glassy carbon disc electrode }\end{array}$ & $\begin{array}{l}4.0 \times 10^{-6} \text { to } 2.0 \times \\
10^{-4} \mathrm{M}\end{array}$ & $\begin{array}{c}4.0 \times 10^{-8} \mathrm{M} \\
(\mathrm{DPV}) \text { and } 1.33 \\
\times 10^{-7} \mathrm{M} \\
(\mathrm{OSWV})\end{array}$ & & 31 \\
\hline \multirow[t]{2}{*}{$\begin{array}{l}\text { Capillary zone electrophoretic (CZE) } \\
\text { and spectrophotometric methods for } \\
\text { determination of QTF }\end{array}$} & $\begin{array}{l}\text { CZE operation with uncoated fused- } \\
\text { silica capillary and a pH } 2.5,50 \\
\text { mM phosphate buffer. UV detection } \\
\text { made at } 205 \mathrm{~nm} \text {, the separation } \\
\text { voltage was } 15 \mathrm{kV} \text {, and a complete } \\
\text { electrophoretic run lasts less than } \\
2.5 \mathrm{~min}\end{array}$ & $5-50 \mu \mathrm{g} \mathrm{mL}^{-1}$ & $0.05 \mu \mathrm{g} \mathrm{mL}{ }^{-1}$ & \multirow[t]{2}{*}{$\begin{array}{l}\text { Nonselective electrophoretic and } \\
\text { spectrophotometric techniques } \\
\text { employed. } \\
\text { Applicable to determine QTF in } \\
\text { tablets. }\end{array}$} & \multirow[t]{2}{*}{32} \\
\hline & $\begin{array}{l}\text { UV spectrometric measurement of } \\
\text { QTF at } 246 \mathrm{~nm} \text { in methanol }\end{array}$ & $5-25 \mu \mathrm{g} \mathrm{mL}-1$ & $1.5 \mu \mathrm{g} \mathrm{mL^{-1 }}$ & & \\
\hline $\begin{array}{l}\text { CZE analysis of QTF using a } 35 \mathrm{~cm} \\
(75 \mu \mathrm{m} \text { id) fused silica capillary and UV } \\
\text { detection at } 214 \mathrm{~nm} \text { at } 10 \mathrm{kV}\end{array}$ & $\begin{array}{l}\text { Separation of four atypical } \\
\text { antipsychotics: clothiapine, } \\
\text { clozapine, olanzapine, } \\
\text { and quetiapine }\end{array}$ & $\begin{array}{c}0.050-0.250 \mathrm{mg} \\
\mathrm{mL}^{-1}\end{array}$ & - & $\begin{array}{l}\text { Applicable to determine QTF in } \\
\text { combination formulations. }\end{array}$ & 33 \\
\hline
\end{tabular}


Comparison of performance characteristics between reported and proposed analytical methods (Continuation)

\begin{tabular}{|c|c|c|c|c|c|}
\hline $\begin{array}{l}\text { Technique and reagents } \\
\text { employed }\end{array}$ & Methodology & $\begin{array}{c}\text { Linear range } \\
\text { for detection of } \\
\text { QTF }\end{array}$ & $\begin{array}{l}\text { Limit of } \\
\text { detection } \\
\text { (LOD) }\end{array}$ & Remarks & $\begin{array}{c}\text { Reference } \\
\text { No. }\end{array}$ \\
\hline $\begin{array}{l}\text { HPTLC technique } \\
\text { TLC Plate: Pre-coated silica gel } 60 \text { F254 } \\
\text { aluminum plates } \\
\text { MP: mixture of methanol and toluene } \\
(4: 3 \% \mathrm{v} / \mathrm{v}) \text {. Densitometric evaluation }\end{array}$ & $\begin{array}{l}\text { Elution study of QTF by HPTLC and } \\
\text { detection by densitometry at } 235 \mathrm{~nm}\end{array}$ & $100-500 \mathrm{ng} / \mathrm{spot}$ & 30 ng/spot & \multirow{4}{*}{$\begin{array}{l}\text { Sophisticated instrument } \\
\text { required. Applicable to determine } \\
\text { QTF in tablets. }\end{array}$} & 34 \\
\hline $\begin{array}{l}\text { NPHPTLC technique } \\
\text { TLC Plate: silica F254 plates } \\
\text { MP: tetrahydrofuran-phosphate buffer, } \\
\text { pH } 9.0,[5: 5(v / v)] \text {. Densitometric and } \\
\text { video densitometric evaluation }\end{array}$ & $\begin{array}{l}\text { Elution study of QTF by NPHPTLC } \\
\text { and detection by densitometry (DM) } \\
\text { and video densitometry (VDM) at } \\
243 \mathrm{~nm}\end{array}$ & $0.2-1.2 \mu \mathrm{g} / \mathrm{spot}$ & $\begin{array}{l}0.02 \mu \mathrm{g} / \mathrm{spot} \\
(\mathrm{DM}) \\
0.04 \mu \mathrm{g} / \mathrm{spot} \\
(\mathrm{VDM})\end{array}$ & & \multirow[t]{2}{*}{35} \\
\hline $\begin{array}{l}\text { RPHPTLC technique } \\
\text { TLC Plate: HPTLC RP8 F254 plates } \\
\text { MP: hexane-dioxane-propylamine } \\
{[1: 9: 0.4(\mathrm{v} / \mathrm{v})] . \text { Densitometric and video }} \\
\text { densitometric tric evaluation }\end{array}$ & $\begin{array}{l}\text { Elution study of QTF by RPHPTLC } \\
\text { and detection by DM and VDM at } \\
254 \mathrm{~nm}\end{array}$ & $0.1-1.1 \mu \mathrm{g} / \mathrm{spot}$ & $\begin{array}{l}0.01 \mu \mathrm{g} / \mathrm{spot} \\
(\mathrm{DM}) \\
0.02 \mu \mathrm{g} / \mathrm{spot} \\
(\mathrm{VDM})\end{array}$ & & \\
\hline $\begin{array}{l}\text { HPTLC technique } \\
\text { TLC Plate: silica gel plates } \\
\text { MP: toluene-methanol 8:2 (v/v). } \\
\text { Densitometric detection }\end{array}$ & $\begin{array}{l}\text { Determination of QTF by HPTLC and } \\
\text { detection by DM at } 254 \mathrm{~nm}\end{array}$ & - & - & & 36 \\
\hline 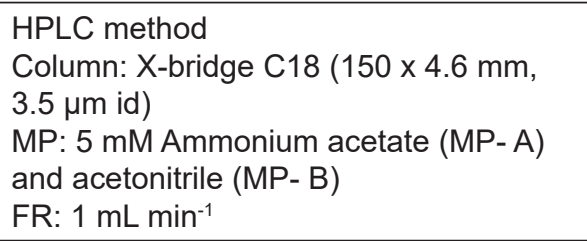 & $\begin{array}{l}\text { HPLC elution and UV detection at } \\
220 \mathrm{~nm}\end{array}$ & - & - & $\begin{array}{l}\text { Sophisticated instrument } \\
\text { required. Applicable for stability } \\
\text { indicating and impurity profile } \\
\text { study of QTF in pharmaceuticals. }\end{array}$ & 37 \\
\hline 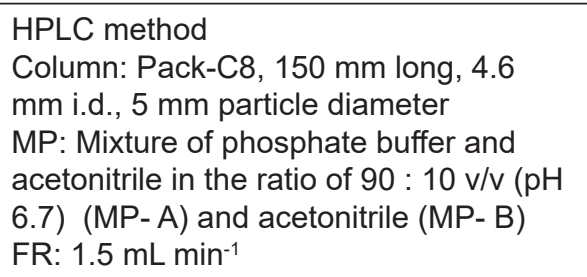 & $\begin{array}{l}\text { RP-HPLC elution of QTF and } \\
\text { detection at } 225 \mathrm{~nm} \text {. } \\
\text { Spectroscopic characterization of } \\
\text { impurities }\end{array}$ & - & - & $\begin{array}{l}\text { Sophisticated analytical } \\
\text { technique required. Applicable } \\
\text { for impurity profile and } \\
\text { characterization studies. }\end{array}$ & 38 \\
\hline
\end{tabular}


Comparison of performance characteristics between reported and proposed analytical methods (Continuation)

\begin{tabular}{|c|c|c|c|c|c|}
\hline $\begin{array}{l}\text { Technique and reagents } \\
\text { employed }\end{array}$ & Methodology & $\begin{array}{c}\text { Linear range } \\
\text { for detection of } \\
\text { QTF }\end{array}$ & $\begin{array}{l}\text { Limit of } \\
\text { detection } \\
\text { (LOD) }\end{array}$ & Remarks & $\begin{array}{l}\text { Reference } \\
\text { No. }\end{array}$ \\
\hline $\begin{array}{l}\text { RP-HPLC method } \\
\text { Column: C18, RRHD } 1.8 \mu \mathrm{m}(50 \mathrm{~mm} x \\
2.1 \mathrm{~mm}) \\
\text { MP: } 0.1 \% \text { aqueous triethylamine } \\
\text { (pH } 7.2)(\text { solvent-A) and mixture of } \\
\text { acetonitrile and methanol in the ratio of } \\
80: 20(\mathrm{v} / \mathrm{v})(\text { Solvent-B) } \\
\text { FR: } 0.5 \mathrm{~mL} \mathrm{~min}-1\end{array}$ & $\begin{array}{l}\text { RP-HPLC elution of QTF and } \\
\text { detection at } 252 \mathrm{~nm}\end{array}$ & $\begin{array}{l}62.5 \text { to } 187.5 \mu \mathrm{g} \\
\mathrm{mL}^{-1}\end{array}$ & - & $\begin{array}{l}\text { Sophisticated instrument } \\
\text { required. }\end{array}$ & 39 \\
\hline RP-HPLC method & Elution of QTF by HPLC & - & - & $\begin{array}{l}\text { Sophisticated instrument } \\
\text { required. Applicable to tablets. }\end{array}$ & 40 \\
\hline $\begin{array}{l}\text { HPLC method } \\
\text { Column: } \mathrm{C} 18(50 \times 4.6 \mathrm{~mm} \text { with } 1.8 \mu \mathrm{m} \\
\text { particles }) \\
\text { MP: Mixture of } 10 \mathrm{mM} \text { potassium } \\
\text { dihydrogen orthophosphate }(\mathrm{pH} 7.0) \\
\text { buffer, methanol and acetonitrile } \\
(450: 300: 250)(\mathrm{v} / \mathrm{v}) \\
\text { FR: } 1.0 \mathrm{~mL} \mathrm{\textrm {min } ^ { - 1 }}\end{array}$ & $\begin{array}{l}\text { Stability of quetiapine hemifumarate } \\
\text { through stress studies using LC } \\
\text { elution and UV detection made at } \\
225 \mathrm{~nm} \text {. }\end{array}$ & Up to $150 \mu \mathrm{g} \mathrm{mL}^{-1}$ & - & $\begin{array}{l}\text { Sophisticated instrument } \\
\text { required. Applicable for stability } \\
\text { indicative and impurity profile } \\
\text { studies. }\end{array}$ & 41 \\
\hline $\begin{array}{l}\text { Isocratic reversed phase ultra- } \\
\text { performance liquid chromatography } \\
\text { (RP-UPLC) } \\
\text { Column: AQUITY UPLC }(2.1 \times 50 \mathrm{~mm} \text {, } \\
1.8 \mu \mathrm{m}) \\
\text { MP: } 30: 70(\mathrm{v} / \mathrm{v}) \text { mixture of potassium } \\
\text { dihydrogen phosphate and dipotassium } \\
\text { hydrogen phosphate (mobile phase } \mathrm{A}) \\
\text { (pH 6.5) and methanol (mobile phase } \mathrm{B} \text { ) }\end{array}$ & $\begin{array}{l}\text { Elution of QTF and UV detection at } \\
252 \mathrm{~nm}\end{array}$ & $1.0-15.0 \mu \mathrm{g} \mathrm{mL} \mathrm{L}^{-1}$ & $0.04 \mu \mathrm{g} \mathrm{ml}^{-1}$ & $\begin{array}{l}\text { Require sophisticated instrument } \\
\text { and larger volumes of toxic } \\
\text { organic solvents. } \\
\text { Applicable to tablets. }\end{array}$ & 42 \\
\hline Spectrophotometric method & $\begin{array}{l}\text { Measurement of QTF at } 290 \mathrm{~nm} \text { in } \\
\text { water }\end{array}$ & $6-54 \mu \mathrm{gL}^{-1}$ & - & $\begin{array}{l}\text { Measurement made at shorter } \\
\text { wavelength. }\end{array}$ & 43 \\
\hline
\end{tabular}


Comparison of performance characteristics between reported and proposed analytical methods (Continuation)

\begin{tabular}{|c|c|c|c|c|c|}
\hline $\begin{array}{l}\text { Technique and reagents } \\
\text { employed }\end{array}$ & Methodology & $\begin{array}{c}\text { Linear range } \\
\text { for detection of } \\
\text { QTF }\end{array}$ & $\begin{array}{l}\text { Limit of } \\
\text { detection } \\
\text { (LOD) }\end{array}$ & Remarks & $\begin{array}{l}\text { Reference } \\
\text { No. }\end{array}$ \\
\hline $\begin{array}{l}\text { Extractive spectrophotometric method } \\
\text { with bromocresol green }\end{array}$ & $\begin{array}{l}\text { Measurement of absorbance of ion- } \\
\text { pair of QTF and bromocresol green } \\
\text { after extracted into chloroform at } 415 \\
\mathrm{~nm}\end{array}$ & $5-25 \mu \mathrm{g} \mathrm{mL}{ }^{-1}$ & $0.29 \mu \mathrm{g} \mathrm{mL}-1$ & \multirow{4}{*}{$\begin{array}{l}\text { Toxic organic solvents are } \\
\text { required. Tedious extraction } \\
\text { procedure is involved. }\end{array}$} & 44 \\
\hline $\begin{array}{l}\text { Extractive spectrophotometric method } \\
\text { with quinolone yellow }\end{array}$ & $\begin{array}{l}\text { Measurement of absorbance of ion- } \\
\text { pair of QTF and quinolone yellow } \\
\text { dye after extracted into chloroform at } \\
420 \mathrm{~nm}\end{array}$ & $2.5-25 \mu \mathrm{g} \mathrm{mL}-1$ & $0.11 \mu \mathrm{g} \mathrm{mL}^{-1}$ & & 45 \\
\hline $\begin{array}{l}\text { Extractive spectrophotometric method } \\
\text { with calmagite }\end{array}$ & $\begin{array}{l}\text { Measurement of absorbance of ion- } \\
\text { pair of QTF and calmagite dye after } \\
\text { extracted into dichloromethane at } \\
490 \mathrm{~nm}\end{array}$ & $3-30 \mu \mathrm{g} \mathrm{mL}^{-1}$ & $0.27 \mu \mathrm{g} \mathrm{mL}^{-1}$ & & 46 \\
\hline $\begin{array}{l}\text { Extractive spectrophotometric method } \\
\text { with bromocresol purple (BCP) and } \\
\text { bromocresol green (BCG) }\end{array}$ & $\begin{array}{l}\text { Measurement of absorbance of ion- } \\
\text { pair complex of QTF with either BCP } \\
\text { at } 406.5 \mathrm{~nm} \text { or BCG at } 416 \mathrm{~nm} \text { in } \\
\text { chloroform. }\end{array}$ & $0.5-20 \mu \mathrm{g} \mathrm{mL}^{-1}$ & $\begin{array}{l}0.12 \mu \mathrm{g} \mathrm{mL}^{-1} \\
(\mathrm{BCP} \text { method); } \\
0.16 \mu \mathrm{g} \mathrm{mL}-1 \\
\text { (BCG method) }\end{array}$ & & 47 \\
\hline \multirow[t]{2}{*}{$\begin{array}{l}\text { Extraction-free spectrophotometric } \\
\text { methods with bromophenol blue (BPB) } \\
\text { and thymol blue (TB) }\end{array}$} & $\begin{array}{l}\text { Measurement of ion-association } \\
\text { complexes formed between QTF in } \\
\text { 1,4-dioxane and BPB in acetone at } \\
410 \mathrm{~nm}\end{array}$ & $1-25 \mu \mathrm{gL}^{-1}$ & $0.21 \mu \mathrm{g} \mathrm{mL}^{-1}$ & \multirow{2}{*}{$\begin{array}{l}\text { Organic solvents are required. } \\
\text { Not applicable to spiked human } \\
\text { urine. }\end{array}$} & \multirow[t]{2}{*}{48} \\
\hline & $\begin{array}{l}\text { Measurement of ion-association } \\
\text { complexes formed between QTF in } \\
\text { TB in acetone at } 380 \mathrm{~nm}\end{array}$ & $1.5-30 \mu \mathrm{g} \mathrm{mL}^{-1}$ & $0.54 \mu \mathrm{g} \mathrm{mL}-1$ & & \\
\hline Ultraviolet spectrophotometric methods & $\begin{array}{l}\text { Measurement of } \\
\text { absorbance of QTF solution in either } \\
0.1 \mathrm{~N} \mathrm{HCl} \text { at } 209 \mathrm{~nm} \\
\text { or in methanol at } 208 \mathrm{~nm}\end{array}$ & $1.25-12.5 \mu \mathrm{g} \mathrm{mL}^{-1}$ & $0.02 \mu \mathrm{g} \mathrm{mL}^{-1}$ & $\begin{array}{l}\text { Toxic organic solvent required. } \\
\text { Shorter wavelengths employed in } \\
\text { the measurement. }\end{array}$ & 49 \\
\hline
\end{tabular}


Comparison of performance characteristics between reported and proposed analytical methods (Continuation)

\begin{tabular}{|c|c|c|c|c|c|}
\hline $\begin{array}{l}\text { Technique and reagents } \\
\text { employed }\end{array}$ & Methodology & $\begin{array}{c}\text { Linear range } \\
\text { for detection of } \\
\text { QTF }\end{array}$ & $\begin{array}{l}\text { Limit of } \\
\text { detection } \\
\text { (LOD) }\end{array}$ & Remarks & $\begin{array}{c}\text { Reference } \\
\text { No. }\end{array}$ \\
\hline Potentiometry with coated wire electrode & $\begin{array}{l}\text { Coated wire electrode construction } \\
\text { using NaTPB ion pair complexing } \\
\text { agent, PVC as supporting matrix, } \\
\text { 2-nitrophenyl octyl ether as mediator } \\
\text { of solvent and potassium tetrakis } \\
\text { (4-chlorophenyl) borate as lipophilic } \\
\text { additive }\end{array}$ & $\begin{array}{c}1 \times 10^{-5} \text { to } 1 \times 10^{-2} \\
\mathrm{~mol} \mathrm{~L}^{-1}\end{array}$ & $3.2 \times 10^{-6} \mathrm{~mol} \mathrm{~L}^{-1}$ & $\begin{array}{l}\text { Coated wire electrode is used. } \\
\text { Usable only up to } 30 \text { days. } \\
\text { Sensor is incompletely validated. }\end{array}$ & 50 \\
\hline \multirow[t]{2}{*}{$\begin{array}{l}\text { Potentiometry with membrane sensors/ } \\
\text { ISEs }\end{array}$} & $\begin{array}{l}\text { Potentiometric determination of QTF } \\
\text { using: } \\
\text { i. QTF-NaTPB ISE }\end{array}$ & $\begin{array}{c}6.25 \times 10^{-5} \text { to } 3.5 \times \\
10^{-3} \mathrm{M}\end{array}$ & $1.56 \times 10^{-5} \mathrm{M}$ & \multirow{2}{*}{$\begin{array}{l}\text { Low cost and easy to handle } \\
\text { instrument is needed. No } \\
\text { stringent experimental } \\
\text { conditions are involved. The } \\
\text { methods employ ecofriendly } \\
\text { and low cost materials and } \\
\text { less energy is consumed in } \\
\text { the analysis. Methods are } \\
\text { adequately sensitive. Analytical } \\
\text { procedures are free from } \\
\text { stringent experimental conditions } \\
\text { such as extraction and sample } \\
\text { preparation by elimination of } \\
\text { interferences. }\end{array}$} & \multirow[t]{2}{*}{$\begin{array}{l}\text { Proposed } \\
\text { work }\end{array}$} \\
\hline & ii. QTF-PTA ISE & & $2.16 \times 10^{-5} \mathrm{M}$ & & \\
\hline
\end{tabular}

